US Army Corps

of Engineers ${ }_{\circledast}$

Engineer Research and

Development Center

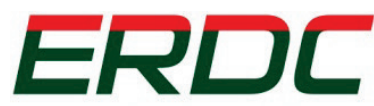

INNOVATIVE SOLUTIONS for a safer, better world

Dredging Operations and Environmental Research Program

\title{
Evaluation of the Use of a Bedleveler to Improve Navigability of Atchafalaya River Bar Channel Fluid Mud
}

Michael Tubman, Timothy Welp, Mike Sullivan,

August 2017

and Chris Colombo

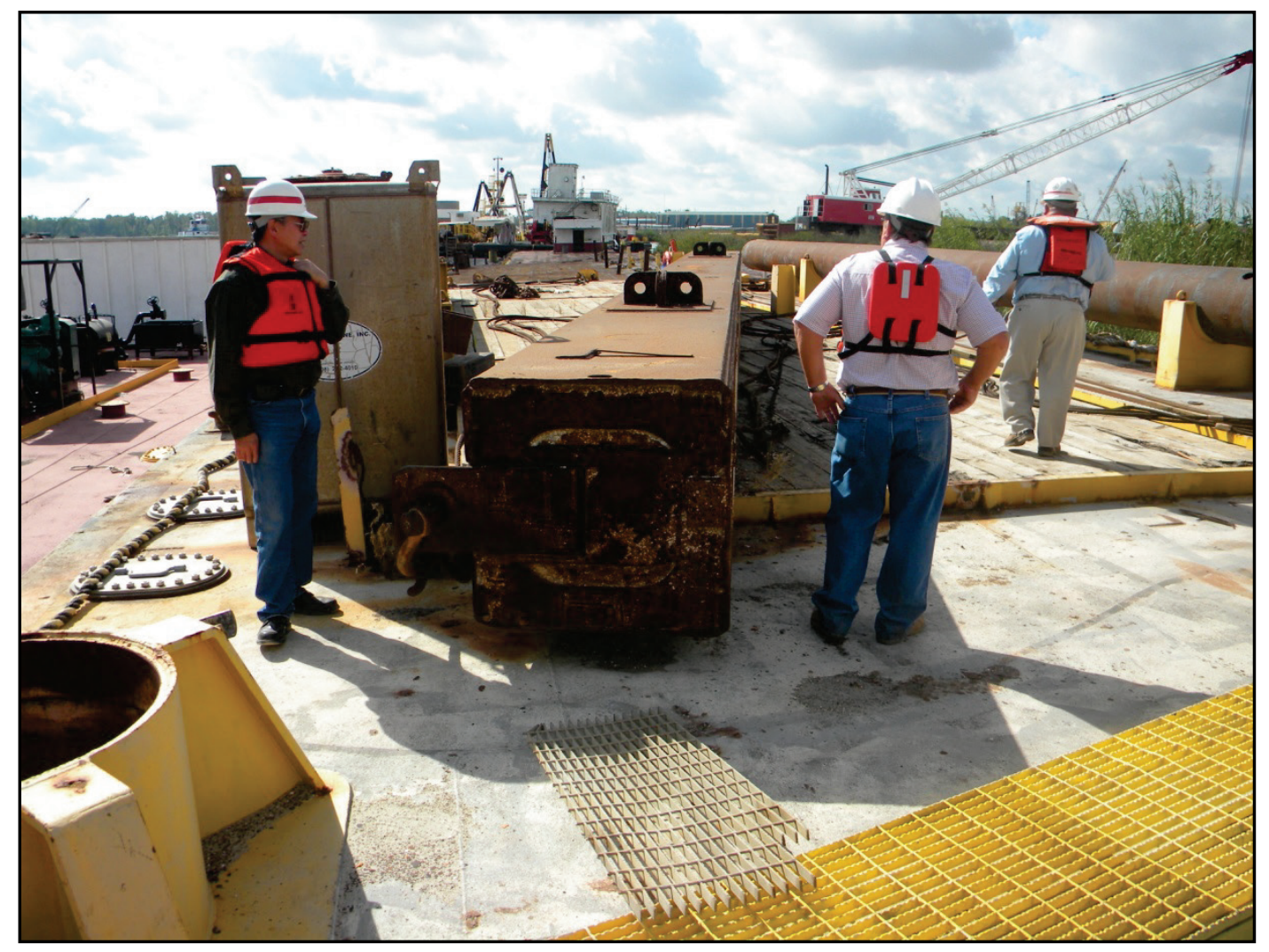


The U.S. Army Engineer Research and Development Center (ERDC) solves the nation's toughest engineering and environmental challenges. ERDC develops innovative solutions in civil and military engineering, geospatial sciences, water resources, and environmental sciences for the Army, the Department of Defense, civilian agencies, and our nation's public good. Find out more at www.erdc.usace.army.mil.

To search for other technical reports published by ERDC, visit the ERDC online library at http://acwc.sdp.sirsi.net/client/default. 


\section{Evaluation of the Use of a Bedleveler to Improve Navigability of Atchafalaya River Bar Channel Fluid Mud}

Michael Tubman and Timothy Welp

Coastal and Hydraulics Laboratory

U.S. Army Engineer Research and Development Center

3909 Halls Ferry Road

Vicksburg, MS 39180-6199

Mike Sullivan and Chris Colombo

U.S. Army Corps of Engineers, New Orleans District 7400 Leake Avenue

New Orleans, LA 70118

Final report

Approved for public release; distribution is unlimited.

Prepared for U.S. Army Corps of Engineers

Washington, DC 20314-1000

Under Work Unit 456009, “Corps Implementation of Nautical Depth” 


\section{Abstract}

Between routine navigation dredging operations, the Atchafalaya River Bar Channel (ABC) traps fluid mud, which begins to consolidate. The consolidated mud can begin to block the passage of vessels using the Port of Morgan City, LA. If the mud densities and yield stresses could be kept sufficiently low so that vessels could safely navigate through it, the length of time between navigation dredging could potentially be increased. To demonstrate the feasibility of dragging a large object through the mud to condition the sediments, a bedleveler was constructed and suspended below a barge at depths that penetrated the interface between the water and the fluid mud in the channel (i.e., the lutocline). The barge was towed along the $\mathrm{ABC}$ parallel to its axis, thereby dragging the bedleveler through the fluid mud on the channel bottom.

It was found that dragging the bedleveler along the channel seemed to have no effect, or an extremely limited effect, over a short duration on the densities. It cannot be ruled out that the bedleveler operations had an effect on yield stresses, but the measured decreases were so inconsistent that naturally occurring changes or other factors had a larger effect.

DISCLAIMER: The contents of this report are not to be used for advertising, publication, or promotional purposes. Citation of trade names does not constitute an official endorsement or approval of the use of such commercial products. All product names and trademarks cited are the property of their respective owners. The findings of this report are not to be construed as an official Department of the Army position unless so designated by other authorized documents. 


\section{Contents}

Abstract
Figures and Tables

2 Test Location and Procedures .......................................................................................... 3

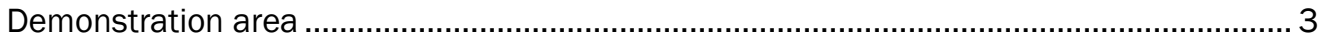

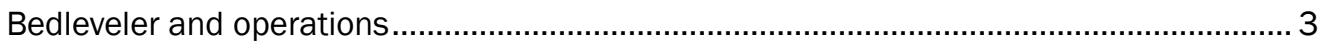

Channel fluid mud surveying ....................................................................................... 6

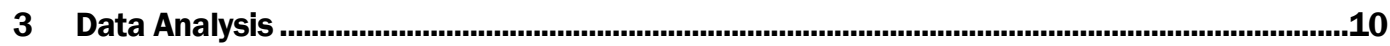

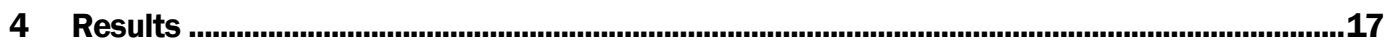

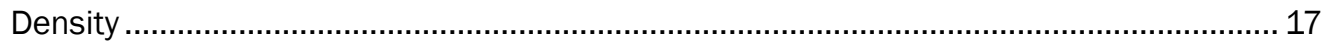

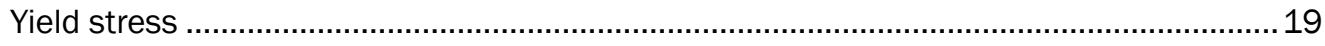

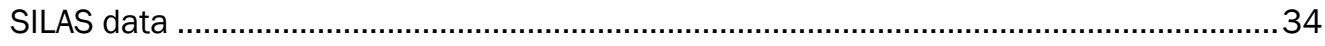

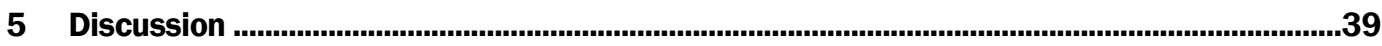

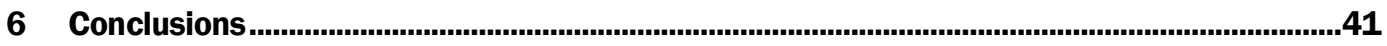

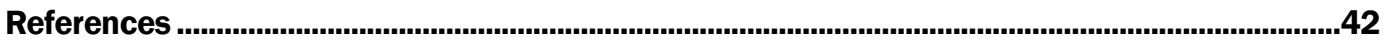

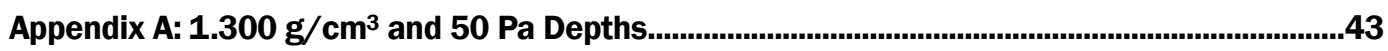

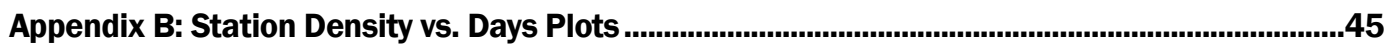

Appendix C: Station Yield Stress vs. Days Plots ................................................................................48

Report Documentation Page 


\section{Figures and Tables}

\section{Figures}

Figure 1. ABC demonstration area with station numbers and Rheotune profile locations (red dots).

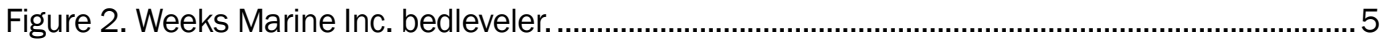

Figure 3. Pushtug Charlie G. towing the plow barge (WEEKS 12).................................................... 5

Figure 4. Rheotune probe being deployed off the TECHE via a semiautomated winch....................... 8

Figure 5. Rheotune density vs. depth (a) and yield stress vs. depth (b) profiles.................................

Figure 6. SILAS acoustically measured density horizon of $1.250 \mathrm{~g} / \mathrm{cm}^{3}$ on 4 December 2011

Figure 7. Example plots of $1.300 \mathrm{~g} / \mathrm{cm}^{3}$ density (a) and 50 Pa yield stress (b) depths plotted vs. time (days) with bedleveler completion day and depth extent indicated by rectangles.

Figure 8. Example of average depths of the 1.250 and $1.300 \mathrm{~g} / \mathrm{cm}^{3}$ density horizons (a) and the 50 Pa horizon depths (b), computed for all 10 surveys.

Figure 9. Vertical profiles of repeated Rheotune yield stress measurements made at the same location.

Figure 10. Before plow-barge operations Rheotune yield-stress profiles at Stations 756 , 762 , and 768

Figure11. Before plow-barge operations Rheotune yield-stress profiles at Stations 780808.

Figure 12. Before plow-barge operations Rheotune yield-stress profiles at Stations 820, 826 , and 832

Figure 13. After plow-barge operations Rheotune yield-stress profiles at Stations 756, 762, and 768.

Figure 14. After plow-barge operations Rheotune yield-stress profiles at Stations 780-820.

Figure 15. After plow-barge operations Rheotune yield-stress profiles at Stations 820, 826 , and 832.

Figure 16. Before (-) and after (-*) plow-barge operations average Rheotune yield-stress profiles at Stations 756,762 , and 768 .

Figure 17. Before (-) and after (-*) plow-barge operations average Rheotune yield-stress profiles at Stations $780-808$.

Figure 18. Before $(-)$ and after $(-*)$ plow-barge operations average Rheotune yield-stress profiles at Stations 820,826 , and 832.

Figure 19. Difference between the average before and after average plow-barge operations profiles at Stations 756,762 , and 768

Figure 20. Difference between the average before and after average plow-barge operations profiles at Stations $780-808$.

Figure 21. Difference between the average before and after average plow-barge operations profiles at Stations 820,826 , and 832. 
Figure 22. SILAS acoustically measured horizons along centerline of ABC. Black trace $1.300 \mathrm{~g} / \mathrm{cm}^{3}$ horizon surveyed 11 November 2011. Red trace $1.300 \mathrm{~g} /$ figure $\mathrm{cm}^{3}$ horizon surveyed 4 December 2011.

Figure 23. SILAS acoustically measured horizons along centerline of ABC. Brown trace $1.250 \mathrm{~g} / \mathrm{cm}^{3}$ horizon surveyed 29 November 2011 . Orange trace $1.250 \mathrm{~g} / \mathrm{cm}^{3}$ horizon surveyed 4 December 2011.

Figure 24. SILAS acoustically measured horizons down centerline of ABC. Orange trace is $1.250 \mathrm{~g} / \mathrm{cm}^{3}$ horizon, and red trace is $1.300 \mathrm{~g} / \mathrm{cm}^{3}$ horizon surveyed 29 November 2011.

\section{Tables}

Table 1. ABC test sections, stations, drag depths, and drag dates........................................................ 4

Table 2. Comparison between Rheotune and laboratory-measured densities..................................... 7

Table 3. Plow-barge operations and list of the dates for the nine surveys........................................10

Table 4. Density statistics determined for all stations. .........................................................................

Table 5. Yield stress derived statistics for all stations....................................................................16

Table 6. Mean densities before and after plow-barge operations at Stations 756, 762, and 768

Table 7. Mean densities before and after plow-barge operations at Stations 780, 784, $788,792,796,800,804$, and 808 .

Table 8. Mean densities before and after plow-barge operations at Stations 820, 826, and 832

Table 9. Before and after plow-barge operations density z-test results.

Table 10. Mean yield stresses before and after plow-barge operations at Stations 756, 762 , and 768.

Table 11. Mean yield stresses before and after plow-barge operations at Stations 780, $784,788,792,796,800,804$, and 808.

Table 12. Mean yield stresses before and after plow-barge operations at Stations 820, 826 , and 832.

Table 13. Before and after plow-barge operations yield stress z-test results.

Table 14. Mean yield stresses before and after plow-barge operations for the stations in Table 3 at a depth of $16 \mathrm{ft}$.

Table 15. Mean yield stresses before and after plow-barge operations for the stations in Table 3 at a depth of $17 \mathrm{ft}$.

Table 16. Mean yield stresses before and after plow-barge operations for the stations in Table 3 at a depth of $18 \mathrm{ft}$.

Table 17. Mean yield stresses before and after plow-barge operations for the stations in Table 3 at a depth of $19 \mathrm{ft}$.

Table 18. Mean yield stresses before and after plow-barge operations for the stations in Table 3 at a depth of $20 \mathrm{ft}$.

Table 19. Mean yield stresses before and after plow-barge operations for the stations in Table 3 at a depth of $21 \mathrm{ft}$.

Table 20. Mean yield stresses before and after plow-barge operations for the stations in Table 3 at a depth of $22 \mathrm{ft}$.

Table A-1. Shallowest depth (ft) where Density (Den) of $1.300 \mathrm{~g} / \mathrm{cm}^{3}$ and Yield Stress (YS) of $50 \mathrm{~Pa}$ were measured (unless otherwise indicated). 


\section{Preface}

This study was conducted for the U.S. Army Corps of Engineers (USACE) under the Dredging Operations and Environmental Research (DOER) Program work unit 456009 "Corps Implementation of Nautical Depth." The USACE Doer Program Manager was Dr. Todd Bridges, Engineer Research and Development Center (ERDC) Environmental Laboratory (EL). At the time this study was conducted, Mr. Jeffrey A. McKee was the USACE Navigation Business Line Manager overseeing the DOER Program. Mr. W. Jeff Lillycrop, ERDC Coastal and Hydraulics Laboratory (CHL), was the Technical Director for Civil Works and Navigation Research, Development, and Technology Transfer (RD\&T) portfolio.

The work was performed by the Coastal Engineering Branch (CEERD-HNC) of the Navigation Division (CEERD-HN) of ERDC CHL. Ms. Tanya Beck was Chief, CEERD-HN-C, and Dr. Jackie Pettway was Chief, CEERD-HN. At the time of this study, Dr. William Martin was Director, ERDC CHL, and Mr. José E. Sánchez was Deputy Director, CHL.

This study documents a monitoring/testing effort at the Atchafalaya Bar Channel to implement the nautical depth concept by USACE in conjunction with the Port of Morgan City, LA. This effort was supported by the USACE New Orleans District (MVN) and by the Port of Morgan City. Appreciation is extended to MVN personnel Ms. Sarah Nash and Mr. Mike Lowe, Project Managers; Mr. Chris Colombo, Chief of Hydrographic Survey; and Mr. Mike Sullivan, Chief Hydrographer; in cooperation with Moffat \& Nichol Engineers representing the Port of Morgan City (Dr. Robert Engler, Mr. Jonathon Hird, and Mr. Maarten Kluijver). Appreciation is also extended to Weeks Marine, Inc., Cranford, NJ, for their cooperation and use of their bedleveler in the execution of these bedleveling operations at the Atchafalaya River Bar Channel.

At the time of publication, the ERDC CHL Director was Mr. José E. Sánchez, and the CHL Deputy Director was Mr. Jeffrey R. Eckstein. Commander of ERDC was COL Bryan S. Green, and the Director of ERDC was Dr. David. W. Pittman. 


\section{Unit Conversion Factors}

Non-SI units of measurement in this report can be converted to SI (metric) units as follows:

\begin{tabular}{|l|c|l|}
\hline Multiply & By & To Obtain \\
\hline feet & 0.3048 & meters \\
\hline miles per hour & 0.44704 & meters per second \\
\hline pound-mass per cubic foot & 16.0185 & grams per cubic centimeter \\
\hline pound-force per square inch & 47.8803 & Pascals \\
\hline
\end{tabular}

Grams per cubic centimeter $\left(\mathrm{g} / \mathrm{cm}^{3}\right)$ can be converted to grams per liter (g/L) by multiplying by 1000 . 


\section{Introduction}

\section{Background}

The Atchafalaya River Bar Channel (ABC) is part of a congressionally authorized navigation route that serves the Port of Morgan City, LA, and is maintained by the U.S. Army Corps of Engineers (USACE) New Orleans District (MVN). It is approximately 16 miles long and 400 feet (ft) wide with a depth of -20 ft Mean Low Gulf (MLG), including an additional $2 \mathrm{ft}$ advanced maintenance and $2 \mathrm{ft}$ allowable overdepth. Between routine navigation dredging operations, the channel traps fluid mud, which consolidates over time. The consolidated mud can begin to block the passage of vessels using the Port. If the mud densities and yield stresses could be kept sufficiently low so that vessels could safely navigate through it, the length of time between navigation dredging could potentially be increased. In addition, if the means of doing this could be quickly and easily implemented, emergency situations where a short length of channel posed a risk to navigation could be dealt with expediently.

Mud densities of approximately 1.2 to 1.3 grams per cubic centimeter $\left(\mathrm{g} / \mathrm{cm}^{3}\right)$ and yield strengths of 50 to 70 Pascals $(\mathrm{Pa})$ have been accepted at ports as being navigable (Wurpts and Greiser 2007). In situ conditioning of sediments can break inter-floc bonds and lower densities and yield strengths. As practiced in Europe, this is accomplished by agitating the fluid mud with a hopper dredge. A simpler and less expensive method of agitating the fluid mud that could potentially have the same result is to stir the mud by dragging a large object through it.

\section{Objective}

The objective of this project was to demonstrate the feasibility of this method to improve navigability in the $\mathrm{ABC}$, a 70,000 pound (lb), $50 \mathrm{ft}$ wide, $3 \mathrm{ft} \times 3 \mathrm{ft}$ beam (commonly referred to as a bedleveler) was constructed and suspended below a barge at depths that penetrated the interface between the water and the fluid mud in the channel (i.e., the lutocline). The barge was towed along the $\mathrm{ABC}$ parallel to its axis, thereby dragging the bedleveler through the fluid mud on the channel bottom. 


\section{Approach}

A Stema Systems survey system consisting of two primary components, a Rheotune and the SILAS, was used to measure fluid mud properties before and after the bedleveler was towed through the fluid mud. The Rheotune is a profiling instrument lowered into the fluid mud from a survey vessel and measures the density and yield stress of the fluid mud. SILAS is a software system with acoustic subbottom reflection signal (in the low-frequency range of 3.5 to 33 kiloHertz [kHz]) acquisition and processing modules. The low-frequency acoustic returns are processed to determine signal attenuation and calibrated for density using the density profiles collected with the Rheotune. This report presents the procedures, measurements, data analysis, and results from the demonstration.

Multiple before- and after-drag Rheotune density and yield stress profiles at fixed stations along the length of the $\mathrm{ABC}$ where the bedleveler was dragged were measured and compared by various methods. In the first comparison, the errors in the profile data were determined to be entirely random and were treated as such. The mean before-drag densities and yield stresses at $1 \mathrm{ft}$ depth intervals were compared to the after-drag means, and the statistical significance of the differences was calculated using a z-test. The second comparison used a subjective method of eliminating entire profiles if they appeared to be shifted. After removing the profiles that appeared to be shifted, the before-and-after means at each $1 \mathrm{ft}$ interval were compared without evaluating the statistical significance of the differences.

SILAS density horizons were also analyzed and plotted to evaluate acoustically measured density values of the before- and after-drag conditions. Plots of the depths of the $1.300 \mathrm{~g} / \mathrm{cm}^{3}$ and $1.250 \mathrm{~g} / \mathrm{cm}^{3}$ fluid mud densities along the full length of the $\mathrm{ABC}$ where the bedleveler was dragged (i.e., the $1.300 \mathrm{~g} / \mathrm{cm}^{3}$ and $1.250 \mathrm{~g} / \mathrm{cm}^{3}$ horizons) were plotted for a survey before any bedleveler drag operations were conducted and for a survey immediately after all bedleveler operations were complete. These plots were examined to determine if there were any consistent, visually obvious differences between the horizons that could be attributed to the drag operations. 


\section{Test Location and Procedures}

\section{Demonstration area}

Figure 1 shows the demonstration area in the Gulf of Mexico near the entrance to Atchafalaya Bay and the Atchafalaya River. The area is in the $\mathrm{ABC}$, the navigation route serving Morgan City, LA, located approximately 28 miles north of the $\mathrm{ABC}$. The $\mathrm{ABC}$ reach selected for the demonstration was originally between Stations 780 and 808, but during the evolution of the demonstration, it was extended to include two additional reaches between Stations 820 and 832 and between Stations 756 and 768 (Figure 1). The added reaches provided test sections for two additional tow depths. The tow depths were chosen to target depths covered by the $3 \mathrm{ft}$ high bedleveler where bottom properties fluctuated about the lutocline (-19 ft), the $1.250-$ $1.300 \mathrm{~g} / \mathrm{cm}^{3}$ density layer $(-21 \mathrm{ft})$, and the 50 Pa yield-stress layer $(-22 \mathrm{ft})$. The ABC test sections, tow depths of the bottom of the bedleveler, and drag dates are listed in Table 1.

\section{Bedleveler and operations}

Bedlevelers, drag beams, and similar devices work by being pulled over the bottom (usually suspended from a vessel by cables or chains), mechanically loosening and dragging the bottom material, and raising it into the water column to be carried away by natural currents. Bedlevelers, while attaining some agitation dredging, are used primarily to reduce the height of bottom material by knocking down or redistributing this material into deeper locations.

Typical bedleveler towing speeds range from 1 to 2 knots. Bedlevelers are used more often in soft sediment maintenance materials and substrate that has never been previously dredged (new work), clay, and even small pieces of rock but are used much less often in sand. The number of passes required depends entirely on the type of material being moved, the height of the ridge to be leveled, and the weight of the bedleveler (USACE 2015). 
Figure 1. $A B C$ demonstration area with station numbers and Rheotune profile locations (red dots).

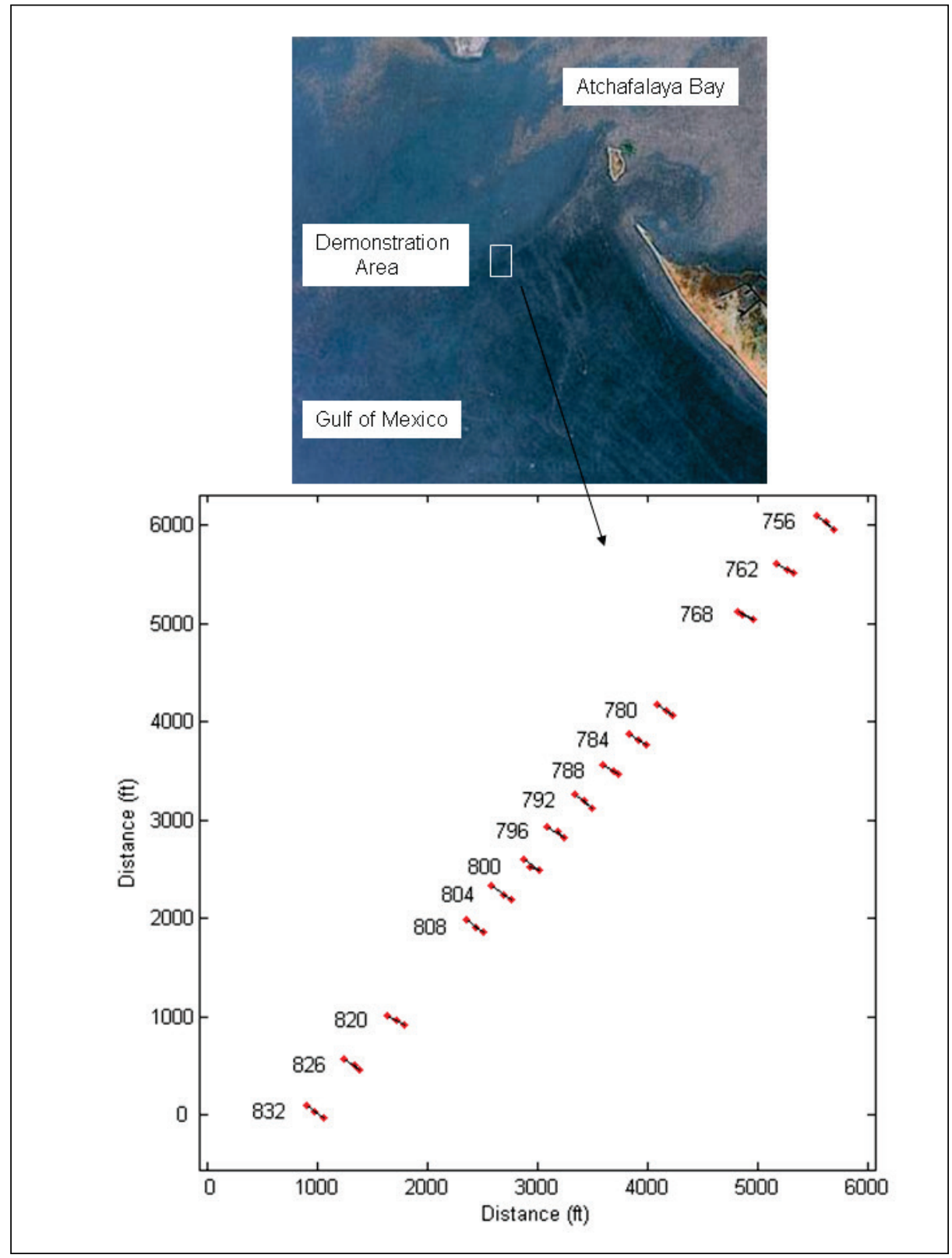

Table 1. ABC test sections, stations, drag depths, and drag dates.

\begin{tabular}{|c|c|c|c|}
\hline Test Sections & Stations Dragged & Depth of Bedleveler (ft) & Drag Date(s) \\
\hline 1 & $780-808$ & -21 & $11 / 30 / 11$ \\
\hline 2 & $820-832$ & -22 & $11 / 20 / 11$ \\
\hline 3 & $756-768$ & -19 & $12 / 2 / 11$ to $12 / 4 / 11$ \\
\hline
\end{tabular}


The 70,000 lb (35 ton), $50 \mathrm{ft}$ wide, $3 \mathrm{ft} \times 3 \mathrm{ft}$ bed leveler (Figure 2) was provided by Weeks Marine, Inc. under a rental contract. The pushtug Charlie G. (1,800 horsepower) (Figure 3) was used to propel the plow barge (WEEKS 12) with the bedleveler suspended beneath it. This barge was originally pushed by the Charlie G., but during initial testing the bedleveler suspension cables were swinging back too far aft to operate efficiently, so the plow barge was towed (as shown in Figure 3) at speeds that ranged (depending on bedleveler depth) from 1.4 to 2.5 miles per hour.

Figure 2. Weeks Marine Inc. bedleveler.

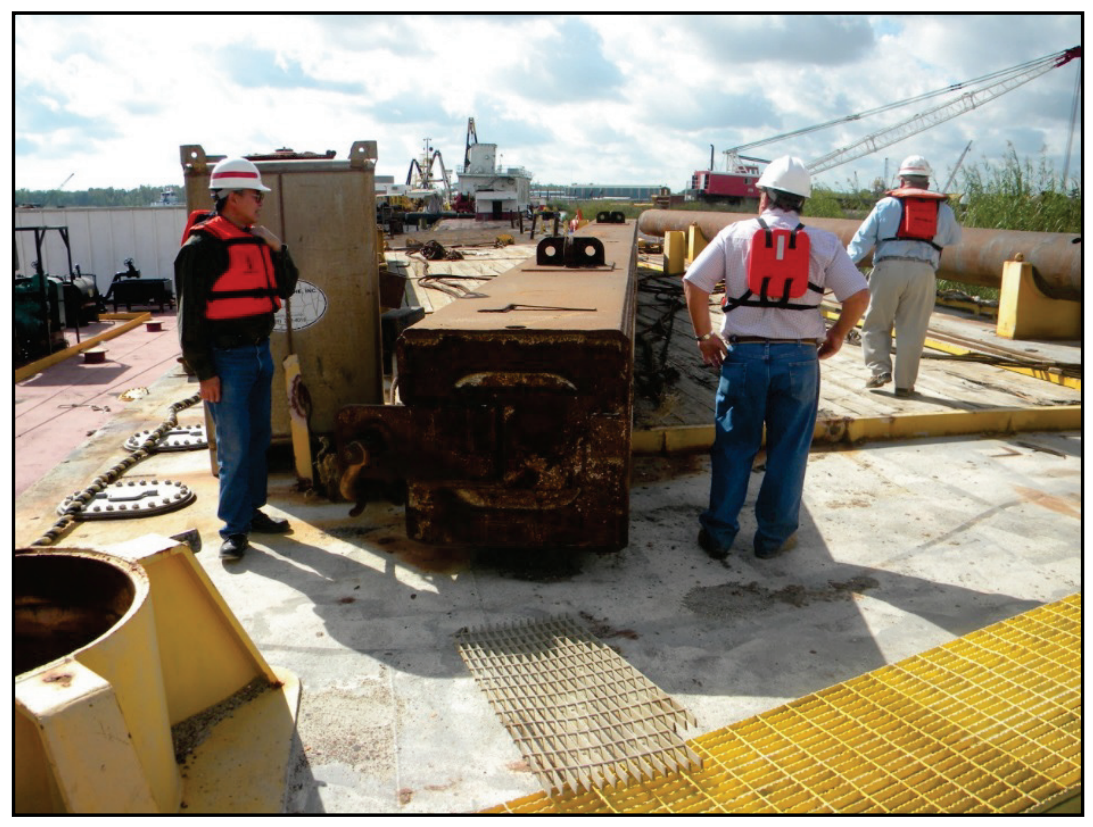

Figure 3. Pushtug Charlie G. towing the plow barge (WEEKS 12).

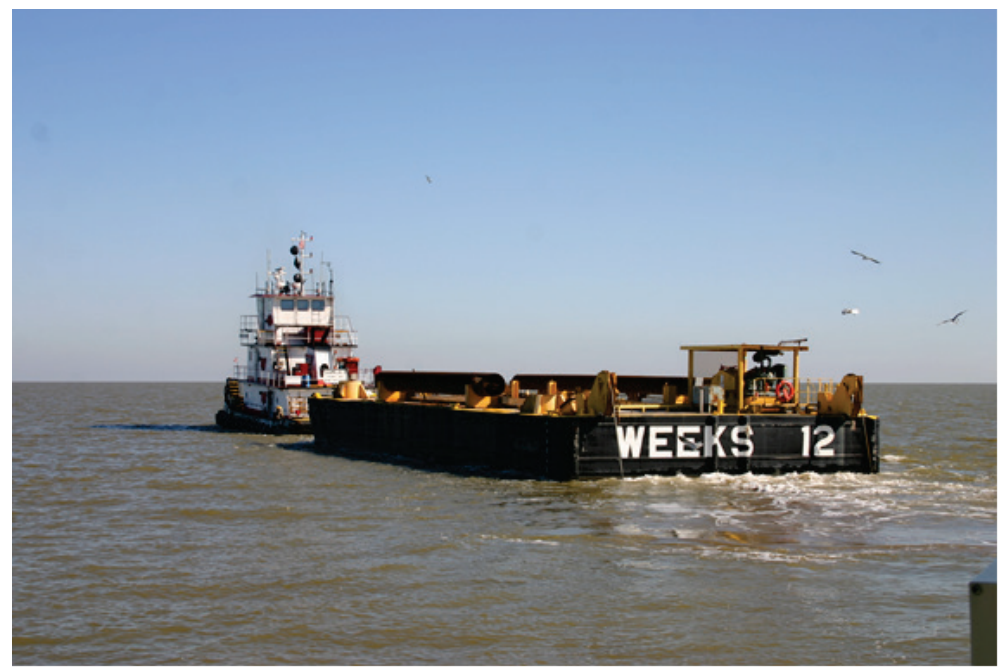


The greater density and yield stress at the bedleveler tow depth, the slower the bedleveler had to be towed. For each setup, the bedleveler was dragged longitudinally along the reach at the designated depth (defined as a run) until the entire width of the channel was dragged (designated as a pass). Four passes were made over each of the three reaches to enhance modification of the properties of the fluid mud. The contractor used a Global Positioning System (GPS) to ensure that the bedleveler was pulled on the intended paths and to ensure that overlaps between adjacent runs were completed. Bedleveler depth was measured manually via graduated paint marks on the suspension wire ropes. The contractor had graduated marks painted on the deck by each winch to verify the accuracy of the marks on the wire ropes. Starting with zero being the place where the bottom of the bedleveler touched the water, the cables were painted in $5.0 \mathrm{ft}$ increments up to $20.0 \mathrm{ft}$ and $1.0 \mathrm{ft}$ increments from 20.0 to $25.0 \mathrm{ft}$. The demonstration began on 30 November 2011 and concluded 4 December 2011. Including downtime and standby time, this resulted in a total dragging time of 72 hours (hr).

\section{Channel fluid mud surveying}

Fluid mud physical characteristics were surveyed by MVN personnel with the Stema system onboard the MVN survey vessel TECHE. The Stema system consists of two primary components, a Rheotune and the SILAS. The Rheotune is a fluid mud profiling probe that operates on the tuning fork principle, with one of the legs of the tuning fork vibrating at a specific frequency and the other leg vibrating at a frequency and amplitude that depend on the density and rheological properties of the medium in which the probe is inserted. The natural resonant frequency of the vibrating fork sensor decreases as the density of the fluid mud increases, and the amplitude of vibrations decrease with increasing viscosity. Thus, measurements of the frequency and amplitude of the vibrating sensor are processed by the Rheotune and result in independent measurements of density and viscosity. In general, the tuning-fork method of measuring density and viscosity is restricted to Newtonian fluids, which continue to flow even when very small forces act on them. Fluid muds of interest in navigation studies generally show non-Newtonian behavior. However, they are enough like a Newtonian fluid that the non-Newtonian behavior can be accounted for by using a proprietary calibration developed by Stema. The Rheotune uses a predefined generalized density calibration based on database values from worldwide natural mud materials. Sitespecific conditions may require modifying the density calibration. 
The yield stress is defined as the stress applied to the mud that is needed to initiate flow. The vibrations of the tuning fork do not impart enough force on typical muds of navigation interest to produce this effect. However, Stema found that the amplitude damping effect could be correlated with yield stress. The amplitude damping effect caused by the viscous behavior of the mud appears from their studies to be uniform in muds of navigation interest. Stema created a database that compares the viscous damping of their tuning fork sensor amplitudes with yield-stress values (measured with a Brookfield viscometer) in muds spanning the range of those of navigation interest. The results of these comparisons are incorporated in the Rheotune calibration, and the Rheotune outputs yieldstress values from its viscosity measurements.

To check the Rheotune's density calibration for the fluid mud present in the ABC, fluid mud was collected from the channel by Ponar grab sampler and placed in a 5 gallon bucket. The Rheotune probe's tuning fork was immersed in the mud and made density measurements. Additional channel water was then added to the bucket, and the mixture was homogenized by stirring to create a less dense suspension. This was done a second time, resulting in measurements of three different densities. Samples were collected from each of these trials and analyzed with a pycnometer for bulk density at the U.S. Army Engineer Research and Development Center (ERDC) Coastal and Hydraulics Laboratory (CHL) and compared with the Rheotune measurements. The comparison results (listed in Table 2) show reasonable expected differences between Rheotune and lab-measured samples for the low, medium, and dense suspensions (0.010 g/ $/ \mathrm{cm}^{3},-0.021 \mathrm{~g} / \mathrm{cm}^{3}$, and $-0.013 \mathrm{~g} / \mathrm{cm}^{3}$, respectively).

Table 2. Comparison between Rheotune and laboratory-measured densities.

\begin{tabular}{|l|c|c|c|c|c|c|}
\hline Mixture & $\begin{array}{l}\text { Rheotune } \\
\text { Density } \\
\left(\mathrm{g} / \mathrm{cm}^{3}\right)\end{array}$ & $\begin{array}{l}\text { Standard } \\
\text { deviation } \\
\left(\mathrm{g} / \mathrm{cm}^{3}\right)\end{array}$ & $\begin{array}{l}\text { Laboratory } \\
\text { Density } \\
\left(\mathrm{g} / \mathrm{cm}^{3}\right)\end{array}$ & $\begin{array}{l}\text { Standard } \\
\text { deviation } \\
\left(\mathrm{g} / \mathrm{cm}^{3}\right)\end{array}$ & $\begin{array}{l}\text { Difference } \\
\left(\mathrm{g} / \mathrm{cm}^{3}\right)\end{array}$ & $\begin{array}{l}\text { Relative } \\
\text { Difference } \\
\text { Percent }(\%)\end{array}$ \\
\hline $\begin{array}{l}\text { Most } \\
\text { Dense }\end{array}$ & 1.280 & 0.0077 & 1.270 & 0.010 & 0.010 & 0.78 \\
\hline $\begin{array}{l}\text { Medium } \\
\text { Dense }\end{array}$ & 1.215 & 0.002 & 1.236 & 0.021 & -0.021 & 1.69 \\
\hline $\begin{array}{l}\text { Least } \\
\text { Dense }\end{array}$ & 1.194 & 0.002 & 1.207 & 0.024 & -0.013 & 1.07 \\
\hline
\end{tabular}


The Rheotune was lowered from the workboat TECHE by a semiautomated winch into the channel (Figure 4) to measure and record water and fluid mud densities and yield stresses as a function of depth. Figure 5 presents examples of the survey systems density vs. depth and yield stress vs. depth profiles at Station 756 .

The SILAS software was developed for the acquisition and processing of acoustic subbottom reflection signals in the low-frequency range of 3.5 to $33 \mathrm{kHz}$. The low-frequency acoustic returns are processed to determine signal attenuation and calibrated for density with the density profiles collected with the Rheotune. SILAS transects were run along the centerline of the channel by the TECHE. An example of SILAS output for the $1.250 \mathrm{~g} / \mathrm{cm}^{3}$ horizon is shown in Figure 6.

Figure 4. Rheotune probe being deployed off the TECHEvia a semiautomated winch.

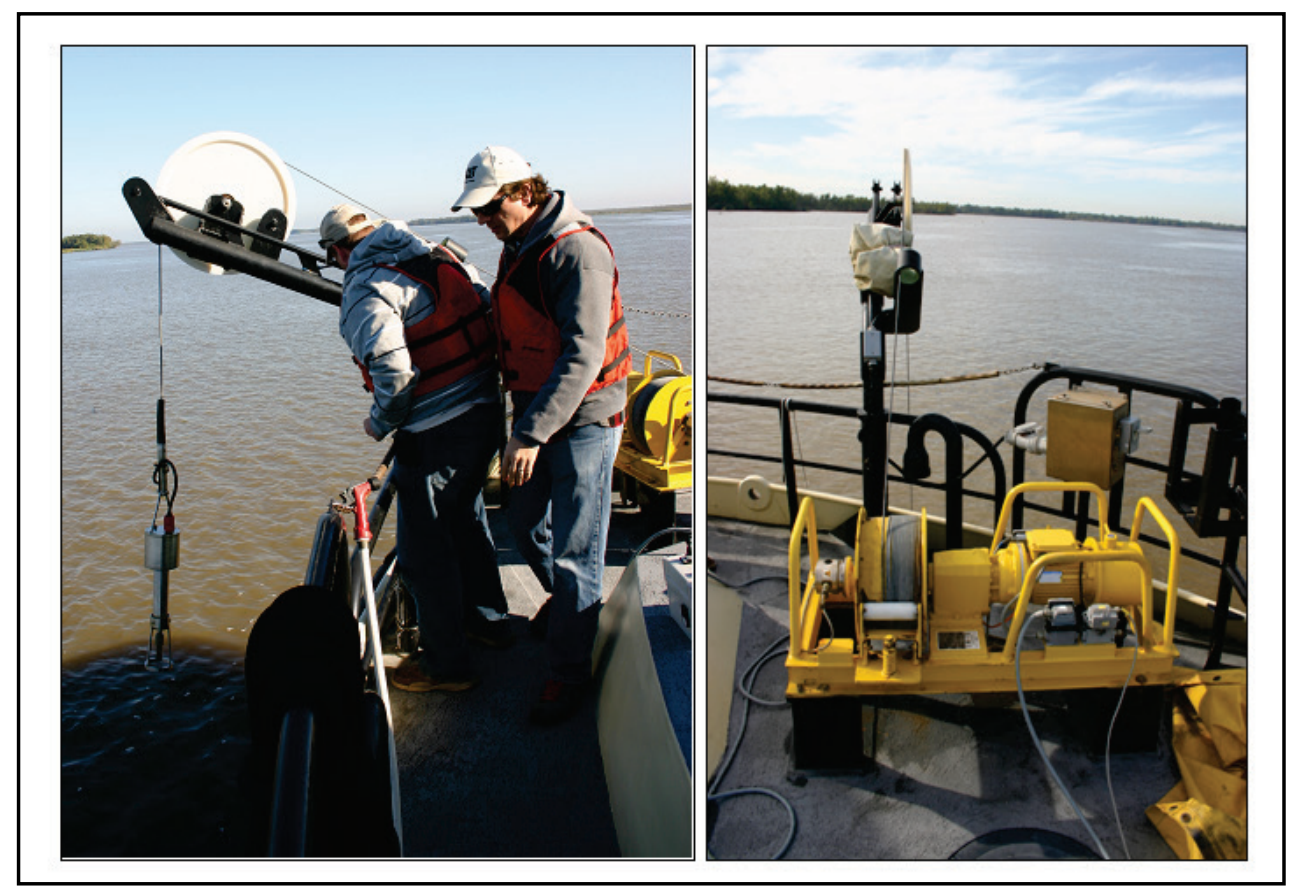


Figure 5. Rheotune density vs. depth (a) and yield stress vs. depth (b) profiles.

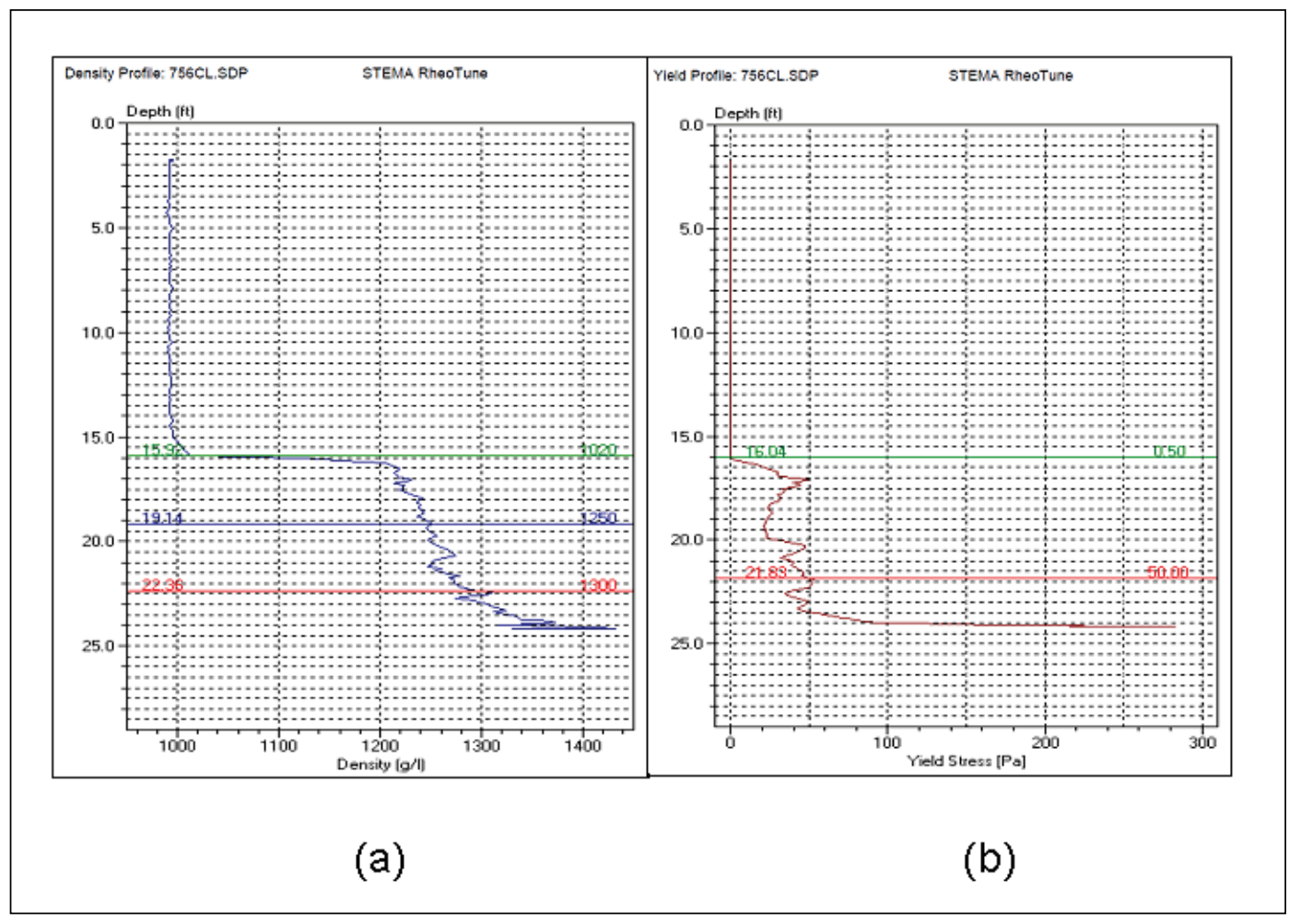

Figure 6. SILAS acoustically measured density horizon of $1.250 \mathrm{~g} / \mathrm{cm}^{3}$ on 4 December 2011.

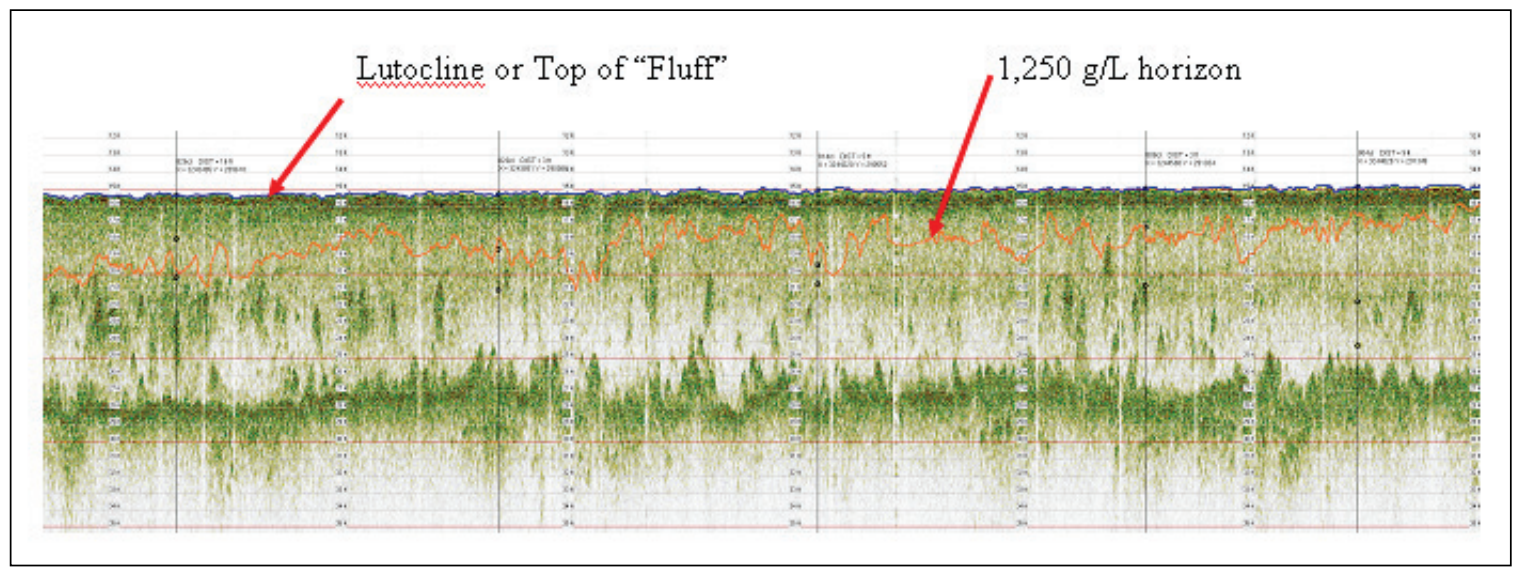




\section{Data Analysis}

The before- and after-drag Rheotune density and yield stress profiles were reduced and compared by various methods described in the following sections. Table 3 lists the stations at which there is Rheotune data, the dates and times at which plow-barge operations occurred at those stations, and the dates of the Rheotune surveys. SILAS density horizons were also analyzed and plotted to evaluate acoustically measured density values of the before- and after-drag conditions.

Table 3. Plow-barge operations and list of the dates for the nine surveys.

\begin{tabular}{|c|c|c|}
\hline Stations & Plow-Barge Operations Dates & \begin{tabular}{|l} 
Surveys \\
Before After
\end{tabular} \\
\hline $\begin{array}{l}780,784,788,792 \\
796,800,804,808\end{array}$ & $11 / 301105-11 / 301810$ & $\begin{array}{l}11 / 2912 / 1-12 / 5 \\
12 / 8,12 / 13 \\
1 / 5\end{array}$ \\
\hline $820,826,832$ & $11 / 301820-11 / 302400$ & $\begin{array}{l}\text { 11/29, 11/30 12/1-12/5, } \\
\text { 12/8, 12/13, } \\
1 / 5\end{array}$ \\
\hline $756,762,768$ & $12 / 22200-12 / 30530$ & $\begin{array}{l}11 / 29-12 / 212 / 3-12 / 5 \\
12 / 8,12 / 13 \\
1 / 5\end{array}$ \\
\hline
\end{tabular}

Before the demonstration was conducted, a density value and yield stress value of $1.300 \mathrm{~g} / \mathrm{cm}^{3}$ and $50 \mathrm{~Pa}$, respectively, were selected as the values where changes in their depths (elevations) could identify navigability changes induced from dragging the bedleveler. The depths where density and yield stresses values reached $1.300 \mathrm{~g} / \mathrm{cm}^{3}$ and $50 \mathrm{~Pa}$ were determined from the Rheotune centerline profiles before and after plow-barge operations and are given in Appendix A. These density and yield stress values were plotted vs. time (days) and are presented in Appendices B and C, respectively. Examples are presented in Figure 7.

The cross-hatched vertical rectangle on these plots illustrates the day that the bedleveler completed the respective pass (from Table 1). Its vertical dimension ( $3 \mathrm{ft}$ ) illustrates the bedleveler's depth extent in relation to the depths at which $1.300 \mathrm{~g} / \mathrm{cm}^{3}$ and 50 Pa were measured. 
Figure 7. Example plots of $1.300 \mathrm{~g} / \mathrm{cm}^{3}$ density (a) and 50 Pa yield stress (b) depths plotted vs. time (days) with bedleveler completion day and depth extent indicated by rectangles.

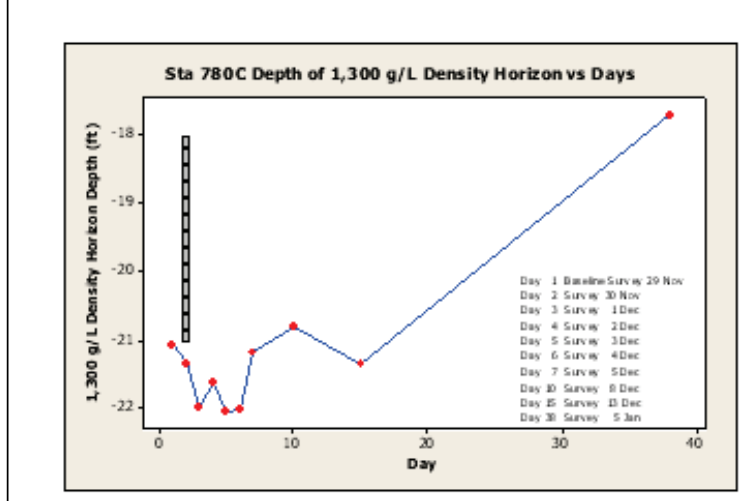

(a)

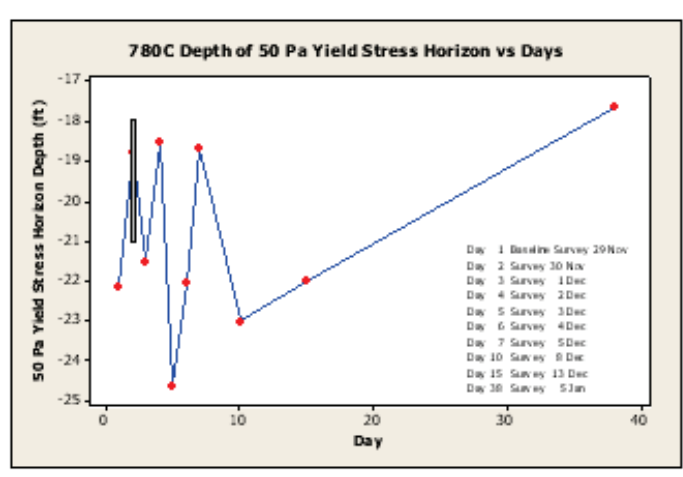

(b)

The density and yield stress horizons shown in Figure 7 and presented in Appendices A through $\mathrm{C}$ were determined by selecting the first measurement in each profile (i.e., the shallowest depth) where the measured density value exceeded $1.300 \mathrm{~g} / \mathrm{cm}^{3}$ or where the measured yield stress exceeded $50 \mathrm{~Pa}$. Another way to analyze the data is to select the depth at which the density or yield stress exceeded a given value and remained greater than that value with increasing depth. This was done for the depths of the $1.250 \mathrm{~g} / \mathrm{cm}^{3}$ density and 50 Pa yield-stress horizons. In a few cases (in 18 out of 280 profiles), single measurements were ignored if they appeared to be greatly different from the measurements above and below them. With these density and yield-stress horizon depths, and those present in Appendix A, averages were computed for each survey with the stations grouped in two ways. Since nearly all the horizon depths were greater than $19 \mathrm{ft}$, one grouping was the three stations $(756,762$, and 768 ) where the drag depth was at $19 \mathrm{ft}$ and most likely would only have an effect on depths 16 to $19 \mathrm{ft}$. The other grouping was the remaining 11 stations where the drag depth was either 21 or $22 \mathrm{ft}$ and could have had an effect on most of the horizon depths. The results are plotted in Figure 8.

In Figure 8, the solid lines are for the $1.250 \mathrm{~g} / \mathrm{cm}^{3}$ and 50 Pa horizons calculated by selecting the depths at which the measurements reached the horizon values and remained above them with increasing depth. The dashed lines are for the horizon depths selected as being for the first depth where the $1.300 \mathrm{~g} / \mathrm{cm}^{3}$ and 50 Pa measurements were exceeded, without the requirement that they remain above these values with increasing depth. The horizontal axis in Figure 8 has uniformly spaced tick marks for each of the 
10 surveys, unlike the plots in Figure 7 that have values for each survey versus a linear scale of days. However, Figure 8 still shows the change in the values with time and does not appear to show any overall long-term trends. To obviously demonstrate the feasibility of dragging the bedleveler to change mud properties, a deepening of the horizons after the baseline survey on 29 November 2011 (the first survey), and a possible recovery of the horizon depths on the last survey on 5 January 12 (32 days after the plow-barge operations were over), would need to be clearly shown in the figure. Presented in this manner, it appears that the tow-barge operations had very little or no effect on navigability. This conclusion led to a statistical analysis of the data to determine if there might be changes that were obscured by measurement errors or natural variability.

Figure 8. Example of average depths of the 1.250 and $1.300 \mathrm{~g} / \mathrm{cm}^{3}$ density horizons (a) and the $50 \mathrm{~Pa}$ horizon depths (b), computed for all 10 surveys.

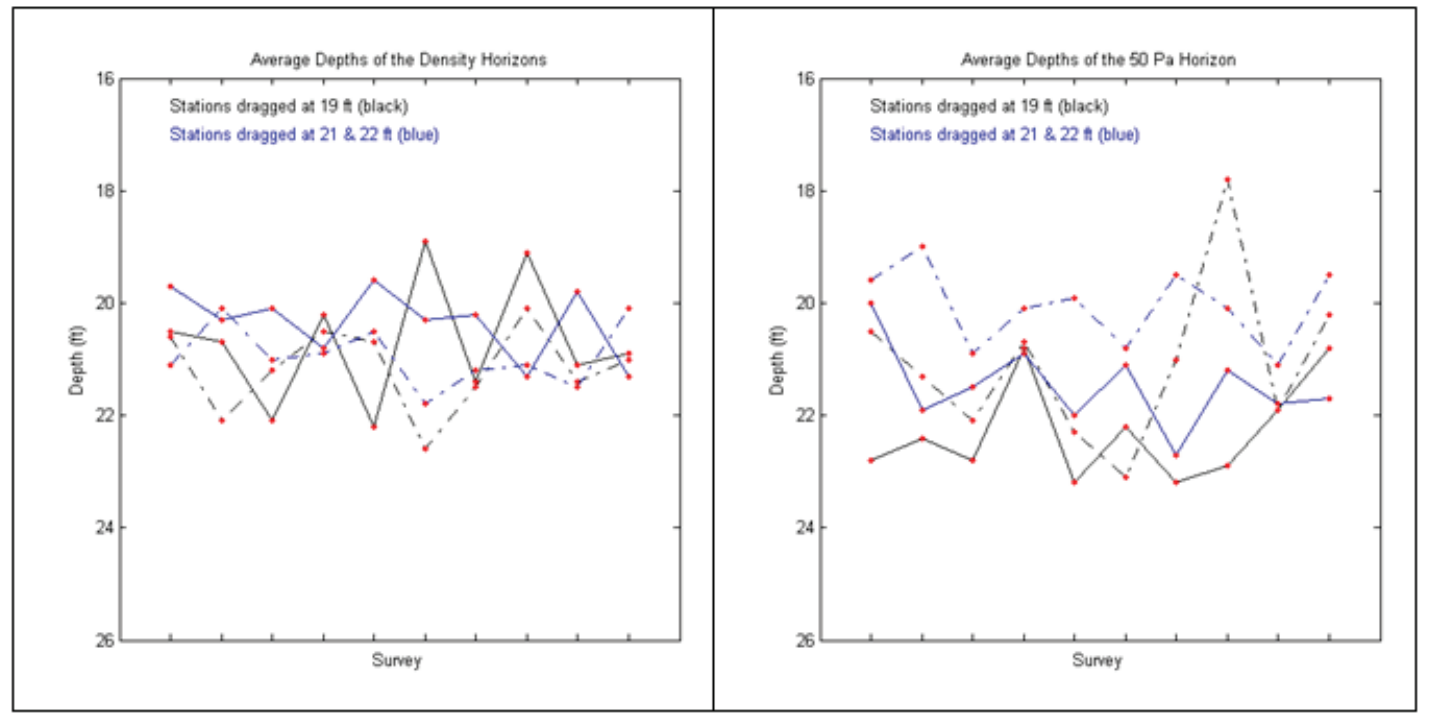

(a)

(b)

The Rheotune data are not error free. There are errors in measured values within individual vertical profiles as well as errors associated with repeatability. The errors in the measured values within individual vertical profiles are of two types. There are random measurement errors typical of any instrument, but there are also apparent data shifts associated with instrument stability. These shifts move entire profiles to unrealistic ranges of values not typical of the measurements made at the same locations 
under similar conditions. The profile shifts aside, the errors associated with repeatability appear to be random errors. These errors result in a range of measured values from repeated profiles made at the same location under the same conditions.

Random errors are described by a Gaussian distribution. The true mean, or average, of a Gaussian distribution of measured values is the measurement that would be expected if there were no errors. The random errors within individual vertical profiles can be reduced by calculating vertical mean values over a distance that is significantly less than the distances over which important changes (i.e., changes that affect navigability) in mud density and yield stress occur.

Figure 9 shows vertical profiles of yield stress made at Station 762 on four consecutive days before plow-barge operations at this station. On the left side of the figure are profiles without any vertical averaging of the data. On the right are profiles of mean values calculated at the depth of each measurement. The means are the averages of the measurements at each depth and the two measurements made immediately before and after the measurements at each depth. This type of mean is referred to as running mean, and for these data it is made over a typical depth range of $0.2 \mathrm{ft}$ above and below each depth where there are data. The profiles of averaged data have the same main features seen in the profiles plotted from data without vertical averaging, but the small scale variations are gone. The Rheotune data were first averaged in this manner at $0.4 \mathrm{ft}$ averaging windows before any analyses were conducted.

The accuracy with which a calculated mean gives the expected value depends on the range of measurement errors quantified by the standard distribution and the number of measured values available for calculating the mean. The greater the number of measurements and the smaller the standard deviation, the closer the calculated mean value is to the expected value. To reduce errors (i.e., improve accuracy) related to repeatability, means were calculated using data from as many before-plow-barge operations surveys as possible and from four after-plow-barge operations surveys. A question arises when analyzing these mean values: Are they close enough to the expected values to show that the expected values are different, or is any difference between them inside the range of values possible in the differences between the calculated means and the expected 
values? This question is tested using a $\mathbf{z}$-test. The $\mathbf{z}$-test statistic, $\mathbf{z}$, gives the probability that the expected values are different and is given by

$$
\mathrm{z}=\frac{\overline{\mathrm{x}_{1}}-\overline{\mathrm{x}_{2}}}{\sqrt{\frac{\sigma_{1}^{2}}{\mathrm{n}_{1}}-\frac{\sigma_{2}^{2}}{\mathrm{n}_{2}}}}
$$

where:

$\overline{\mathrm{x}_{1}}$ and $\overline{\mathrm{x}_{2}}=$ the before and after mean yield stresses

$\sigma_{1}$ and $\sigma_{2}=$ the before and after standard deviations

$\mathrm{n}_{1}$ and $\mathrm{n}_{2}=$ the before-and-after number of measurements.

Figure 9. Vertical profiles of repeated Rheotune yield stress measurements made at the same location.

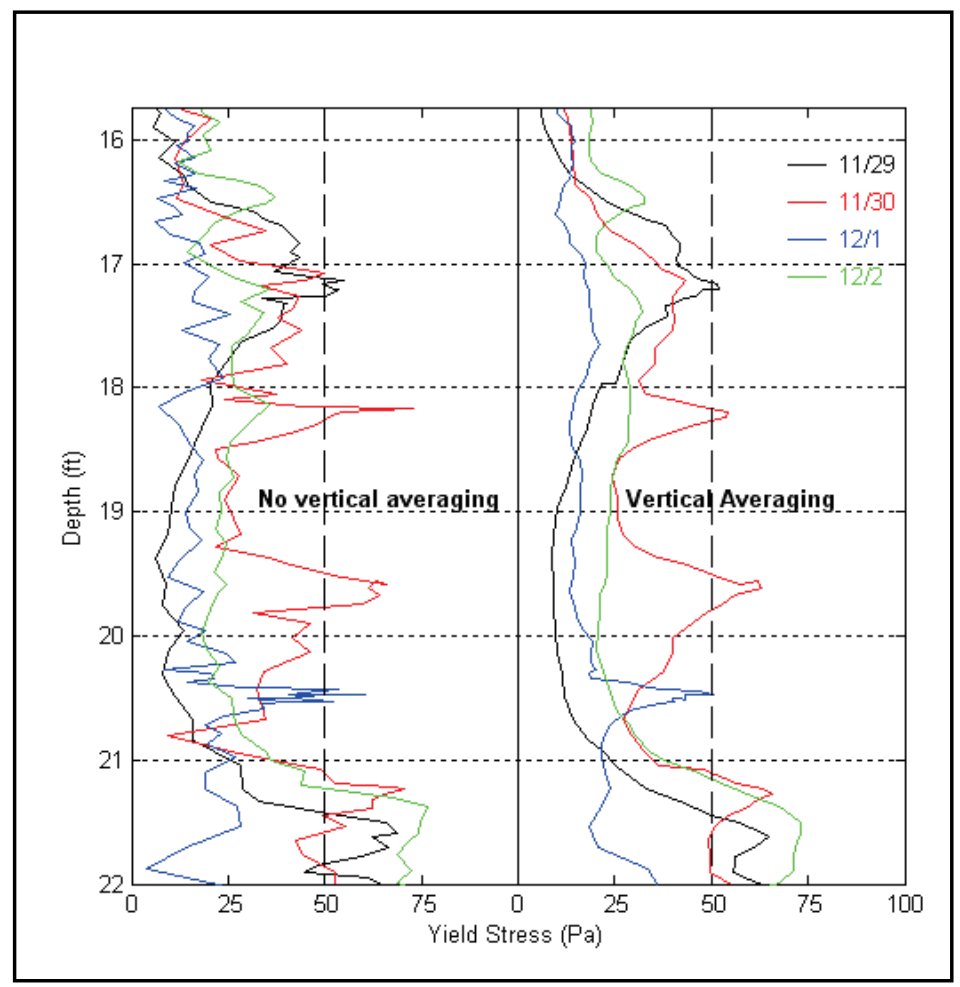

The observed shifted profiles cannot be considered to be random errors for these Rheotune data. However, the data values might be eliminated by a common statistical practice of eliminating measurements that are three standard deviations different than the mean. This was done in the first of the following two data analyses types. The first type of analysis treats all the errors as being random and eliminates measurements that are greater 
than three standard deviations from the mean. To calculate the means and the standard deviations for the data elimination criteria, an assumption is made that any changes in density or yield stress that result from plowbarge operations are much smaller than three standard deviations from the means at each depth for all surveys (i.e., data from both before and after operations). This assumption is shown by the analyses to be valid.

The second type of data analyses introduces a subjective element. It eliminates entire profiles from the analysis if they appear to be shifted. There is no elimination of individual measurements based on their value relative to the mean. The second analysis was conducted to test the sensitivity of the conclusions made on the basis of the first type of analyses, compared to the treatment of all errors as being random.

The data elimination criteria based on the standard deviations were established by calculating the means and standard deviations of measurements for all surveys starting at $16 \mathrm{ft}$ depth. Then the elimination criteria imposed from the analysis was applied if values were less than the water density $\left(1.007 \mathrm{~g} / \mathrm{cm}^{3}\right)$ or greater than the Rheotune penetration density at the 17, 18, 19, 20, 21, and $22 \mathrm{ft}$ depths. For the density data, there was an additional initial criteria imposed that eliminated measurements from the analysis if they were less than the water density $\left(1.007 \mathrm{~g} / \mathrm{cm}^{3}\right)$ or greater than the Rheotune penetration density $\left(1.350 \mathrm{~g} / \mathrm{cm}^{3}\right)$. For the yield stress data, an initial criteria eliminated measurements greater than a physically unrealistic value of $250 \mathrm{~Pa}$. The results for the density data are listed in Table 4. Table 5 lists the results for the yield-stress data.

Table 4. Density statistics determined for all stations.

\begin{tabular}{|c|c|c|c|}
\hline Depth (MLG ft) & Mean Density $\left(\mathrm{g} / \mathrm{cm}^{3}\right)$ & $\begin{array}{l}\text { Standard Deviation } \\
\left(\mathrm{g} / \mathrm{cm}^{3}\right)\end{array}$ & $\begin{array}{l}\text { 3 Standard Deviations } \\
+ \text { Mean* }\left(\mathrm{g} / \mathrm{cm}^{3}\right)\end{array}$ \\
\hline 16 & 1.192 & 0.036 & 1.300 \\
\hline 17 & 1.218 & 0.032 & 1.313 \\
\hline 18 & 1.227 & 0.036 & 1.335 \\
\hline 19 & 1.237 & 0.038 & 1.350 \\
\hline 20 & 1.250 & 0.044 & 1.350 \\
\hline 21 & 1.266 & 0.049 & 1.350 \\
\hline 22 & 1.285 & 0.050 & 1.350 \\
\hline
\end{tabular}

* Maximum density the Rheotune can penetrate is taken to be $1.350 \mathrm{~g} / \mathrm{cm}^{3}$. 
Table 5. Yield stress derived statistics for all stations.

\begin{tabular}{|c|c|c|c|}
\hline Depth (MLG ft) & $\begin{array}{l}\text { Mean Yield Stress } \\
(\mathbf{P a})\end{array}$ & $\begin{array}{l}\text { Standard Deviation } \\
\mathbf{( P a})\end{array}$ & $\begin{array}{l}\text { 3 Standard Deviations } \\
+ \text { Mean }(\mathrm{Pa})\end{array}$ \\
\hline 16 & 7.4 & 8.1 & 31.6 \\
\hline 17 & 19.0 & 15.6 & 65.7 \\
\hline 18 & 26.7 & 19.8 & 86.2 \\
\hline 19 & 33.6 & 28.7 & 119.8 \\
\hline 20 & 37.9 & 32.0 & 134.0 \\
\hline 21 & 45.9 & 27.7 & 129.0 \\
\hline 22 & 61.4 & 32.6 & 159.1 \\
\hline
\end{tabular}




\section{Results}

\section{Density}

Tables 6, 7, and 8 list the average before- and after-plow-barge operations densities at each depth. In these tables, the averages and standard deviations are computed using values for all stations affected by each operation, at each depth, from each survey. Rheotune survey data are available for varying numbers of days surrounding each plow-barge operation. For all three operations, there are 4 days of data available after each operation. For the third operation (Table 6), there are also 4 days of data available from before the operation. For the second operation (Table 7), there was only one survey conducted before the operation began. There was another survey conducted on 30 November 2011 shortly after that operation began when it was only $25 \%$ complete. Data from that survey are not used in the analyses. For the first operation (Table 8), there were two surveys done before the operation began. The dates of the surveys used in the analyses are listed in the tables.

Table 6. Mean densities before and after plow-barge operations at Stations 756,762 , and 768.

\begin{tabular}{|c|c|c|c|c|}
\hline \multirow[b]{2}{*}{$\begin{array}{l}\text { Depth } \\
\text { (MLG ft) }\end{array}$} & \multicolumn{2}{|c|}{$11 / 29 / 11-12 / 2 / 11$} & \multicolumn{2}{|c|}{$12 / 3 / 11-12 / 8 / 11$} \\
\hline & $\begin{array}{l}\text { Mean Density } \\
\left(\mathrm{g} / \mathrm{cm}^{3}\right)\end{array}$ & $\begin{array}{l}\text { Standard } \\
\text { Deviation }\left(\mathrm{g} / \mathrm{cm}^{3}\right)\end{array}$ & $\begin{array}{l}\text { Mean Density } \\
\left(\mathrm{g} / \mathrm{cm}^{3}\right)\end{array}$ & $\begin{array}{l}\text { Standard Deviation } \\
\left(\mathrm{g} / \mathrm{cm}^{3}\right)\end{array}$ \\
\hline 16 & $1.178^{*}$ & 0.019 & 1.183 & 0.041 \\
\hline 17 & 1.220 & 0.016 & 1.224 & 0.017 \\
\hline 18 & 1.231 & 0.009 & 1.231 & 0.027 \\
\hline 19 & 1.235 & 0.029 & 1.250 & 0.009 \\
\hline 20 & 1.251 & 0.006 & 1.252 & 0.011 \\
\hline 21 & 1.253 & 0.029 & 1.265 & 0.029 \\
\hline 22 & $1.279^{1}$ & 0.022 & 1.278 & 0.023 \\
\hline
\end{tabular}

*No data on 11/29 at Station 756.

1 No data on 11/29 at Station 768 . 
Table 7. Mean densities before and after plow-barge operations at Stations $780,784,788$, $792,796,800,804$, and 808.

\begin{tabular}{|c|c|c|c|c|}
\hline \multirow[b]{2}{*}{ Depth (MLG ft) } & \multicolumn{2}{|c|}{$11 / 29 / 11$} & \multicolumn{2}{|c|}{$12 / 1 / 11-12 / 4 / 11$} \\
\hline & $\begin{array}{l}\text { Mean Density } \\
\left(\mathrm{g} / \mathrm{cm}^{3}\right)\end{array}$ & \begin{tabular}{|l|} 
Standard \\
Deviation $\left(\mathrm{g} / \mathrm{cm}^{3}\right)$
\end{tabular} & \begin{tabular}{|l|} 
Mean Density \\
$\left(\mathrm{g} / \mathrm{cm}^{3}\right)$
\end{tabular} & \begin{tabular}{|l|} 
Standard \\
Deviation $\left(\mathrm{g} / \mathrm{cm}^{3}\right)$
\end{tabular} \\
\hline 16 & 1.198 & 0.043 & 1.204 & 0.030 \\
\hline 17 & 1.218 & 0.046 & 1.217 & 0.031 \\
\hline 18 & 1.232 & 0.039 & 1.226 & 0.034 \\
\hline 19 & 1.246 & 0.045 & 1.237 & 0.033 \\
\hline 20 & 1.238 & 0.052 & 1.252 & 0.031 \\
\hline 21 & 1.258 & 0.053 & 1.271 & 0.041 \\
\hline 22 & 1.291 & 0.054 & $1.301^{*}$ & 0.044 \\
\hline
\end{tabular}

${ }^{*}$ Measurement at Station 804 on 12/2 not included because it exceeded 1,350 g/cm³.

Table 8. Mean densities before and after plow-barge operations at Stations 820, 826, and 832.

\begin{tabular}{|c|c|c|c|c|}
\hline \multirow[b]{2}{*}{ Depth (MLG ft) } & \multicolumn{2}{|c|}{$11 / 29 / 11-11 / 30 / 11$} & \multicolumn{2}{|c|}{$12 / 1 / 11-12 / 4 / 11$} \\
\hline & $\begin{array}{l}\text { Mean Density } \\
\left(\mathrm{g} / \mathrm{cm}^{3}\right)\end{array}$ & $\begin{array}{l}\text { Standard } \\
\text { Deviation }\left(\mathrm{g} / \mathrm{cm}^{3}\right)\end{array}$ & $\begin{array}{l}\text { Mean Density } \\
\left(\mathrm{g} / \mathrm{cm}^{3}\right)\end{array}$ & $\begin{array}{l}\text { Standard } \\
\text { Deviation }\left(\mathrm{g} / \mathrm{cm}^{3}\right)\end{array}$ \\
\hline 16 & 1.187 & 0.029 & 1.182 & 0.036 \\
\hline 17 & 1.212 & 0.028 & 1.215 & 0.015 \\
\hline 18 & 1.246 & 0.018 & 1.234 & 0.016 \\
\hline 19 & 1.262 & 0.014 & 1.260 & 0.016 \\
\hline 20 & 1.290 & 0.020 & 1.268 & 0.053 \\
\hline 21 & 1.301 & 0.017 & 1.288 & 0.060 \\
\hline 22 & $1.302 *$ & 0.040 & $1.295^{1,2}$ & 0.061 \\
\hline
\end{tabular}

*No data on $11 / 29$ at Station 826.

${ }^{1}$ Measurement at Station 820 on 12/2 not included because it exceeded $1.350 \mathrm{~g} / \mathrm{cm}^{3} .{ }^{2}$ Measurement at Station 826 on $12 / 4$ not included because it exceeded $1.350 \mathrm{~g} / \mathrm{cm}^{3}$.

Table 9 lists the probabilities based on the z-test value that the before- and after-plow-barge operations mean densities are not due to random error. Only three of the probabilities in Table 9 are greater than or equal to $75 \%$, and there are an equal number (i.e., 10) of decreased and increased densities between the before-plow-barge operations and after-plow-barge operations. This indicates that the differences in the densities measured after the plow-barge operations and those measured before the plow-barge operations are likely due to chance. The conclusion from this is that the plow-barge had no demonstrated effect on mud density. 
Table 9. Before and after plow-barge operations density z-test results.

\begin{tabular}{|c|c|c|}
\hline Depth (MLG ft) & $Z$ value & Probability (\%) \\
\hline & \multicolumn{2}{|c|}{ Stations 756,762 , and 768} \\
\hline 16 & -0.38 & 30 \\
\hline 17 & -0.59 & 44 \\
\hline 18 & 0 & 0 \\
\hline 19 & -1.71 & 91 \\
\hline 20 & -0.28 & 22 \\
\hline 21 & -1.01 & 69 \\
\hline \multirow[t]{2}{*}{22} & 0.11 & 9 \\
\hline & \multicolumn{2}{|c|}{ Stations $780,784,788,792,796,800,804$, and 808} \\
\hline 16 & -0.37 & 29 \\
\hline 17 & 0.06 & 5 \\
\hline 18 & 0.40 & 31 \\
\hline 19 & 0.53 & 40 \\
\hline 20 & -0.73 & 53 \\
\hline 21 & -0.65 & 48 \\
\hline \multirow[t]{2}{*}{22} & -0.48 & 37 \\
\hline & \multicolumn{2}{|c|}{ Stations 820,826 , and 832} \\
\hline 16 & 0.32 & 25 \\
\hline 17 & -0.25 & 19 \\
\hline 18 & 1.38 & 83 \\
\hline 19 & 0.27 & 21 \\
\hline 20 & 1.27 & 80 \\
\hline 21 & 0.70 & 52 \\
\hline 22 & 0.27 & 21 \\
\hline
\end{tabular}

\section{Yield stress}

The before- and after-plow-barge operations yield stress means and standard deviations are listed in Tables 10, 11, and 12, and the probabilities are listed in Table 13. The probabilities that the differences are not due to chance are greater than or equal to $75 \%$ in nine cases: at $18,19,20$, and $22 \mathrm{ft}$ at Stations 756, 762, and 768; at 16 and $22 \mathrm{ft}$ at Stations 780 through 808 ; and at 18, 19, and $20 \mathrm{ft}$ at Stations 820, 826, and 832. In each of these nine cases, the $\mathrm{z}$ value is positive, meaning that the yield stress was lower after the plow-barge operations. 
Table 10. Mean yield stresses before and after plow-barge operations at Stations 756, 762, and 768.

\begin{tabular}{|c|c|c|c|c|}
\hline \multirow{2}{*}{$\begin{array}{c}\text { Depth } \\
\text { (MLG ft) }\end{array}$} & \multicolumn{2}{|c|}{ 11/29/11-12/2/11 } & \multicolumn{2}{c|}{ 12/3/11-12/8/11 } \\
\cline { 2 - 5 } & $\begin{array}{l}\text { Mean Yield } \\
\text { Stress (Pa) }\end{array}$ & $\begin{array}{l}\text { Standard } \\
\text { Deviation (Pa) }\end{array}$ & $\begin{array}{l}\text { Mean Yield } \\
\text { Stress (Pa) }\end{array}$ & $\begin{array}{l}\text { Standard } \\
\text { Deviation (Pa) }\end{array}$ \\
\hline 16 & $3.2^{*}$ & 2.0 & 5.7 & 8.5 \\
\hline 17 & 20.6 & 10.4 & 21.2 & 17.4 \\
\hline 18 & 30.3 & 20.2 & 21.2 & 11.8 \\
\hline 19 & 28.9 & 22.5 & 20.9 & 9.1 \\
\hline 20 & 26.0 & 24.5 & 16.4 & 5.8 \\
\hline 21 & 30.4 & 21.6 & 28.9 & 18.3 \\
\hline 22 & $40.1^{1}$ & 18.1 & 30.7 & 16.0 \\
\hline
\end{tabular}

${ }^{*}$ No data on $11 / 29$ at Station $756 .{ }^{1}$ No data on $11 / 29$ at Station 768.

Table 11. Mean yield stresses before and after plow-barge operations at Stations 780, 784, $788,792,796,800,804$, and 808.

\begin{tabular}{|c|c|c|c|c|}
\hline \multirow{2}{*}{$\begin{array}{c}\text { Depth } \\
\text { (MLG ft) }\end{array}$} & \multicolumn{2}{|c|}{ 11/29/11 } & \multicolumn{2}{c|}{ 12/1/11-12/4/11 } \\
\cline { 2 - 5 } & $\begin{array}{l}\text { Mean Yield } \\
\text { Stress (Pa) }\end{array}$ & $\begin{array}{l}\text { Standard } \\
\text { Deviation (Pa) }\end{array}$ & $\begin{array}{l}\text { Mean Yield } \\
\text { Stress (Pa) }\end{array}$ & $\begin{array}{l}\text { Standard } \\
\text { Deviation (Pa) }\end{array}$ \\
\hline 16 & $12.4^{*}$ & 5.2 & $9.2^{1,2}$ & 5.6 \\
\hline 17 & 25.0 & 14.6 & $20.5^{3}$ & 10.4 \\
\hline 18 & $27.4^{4}$ & 10.3 & 27.9 & 12.3 \\
\hline 19 & 33.9 & 26.8 & 37.6 & 19.7 \\
\hline 20 & 46.0 & 32.9 & 41.1 & 18.7 \\
\hline 21 & 53.2 & 26.1 & $44.2^{5}$ & 16.5 \\
\hline 22 & 76.9 & 31.2 & $59.4^{5}$ & 15.2 \\
\hline
\end{tabular}

* Measurement at Station 800 on 11/29 not included because it exceeded 3 standard deviations. 1 Measurement at Station 784 on 12/4 not included because it exceeded 3 standard deviations. 2Measurement at Station 804 on 12/3 not included because it exceeded 3 standard deviations. 3Measurement at Station 804 on 12/4 not included because it exceeded 3 standard deviations. 4 Measurement at Station 800 on 11/29 not included because it exceeded 3 standard deviations. 5 Measurements at Station 800 on 12/2 not included because they exceeded 3 standard deviations. 
Table 12. Mean yield stresses before and after plow-barge operations at Stations 820, 826, and 832.

\begin{tabular}{|c|c|c|c|c|}
\hline \multirow{2}{*}{$\begin{array}{c}\text { Depth } \\
\text { (MLG ft) }\end{array}$} & \multicolumn{2}{|c|}{$11 / 29 / 11-11 / 30 / 11$} & \multicolumn{2}{c|}{ 12/1/11-12/4/11 } \\
\cline { 2 - 5 } & $\begin{array}{l}\text { Mean Yield } \\
\text { Stress (Pa) }\end{array}$ & $\begin{array}{l}\text { Standard } \\
\text { Deviation (Pa) }\end{array}$ & $\begin{array}{l}\text { Mean Yield } \\
\text { Stress (Pa) }\end{array}$ & $\begin{array}{l}\text { Standard } \\
\text { Deviation (Pa) }\end{array}$ \\
\hline 16 & 6.7 & 6.5 & 3.8 & 3.8 \\
\hline 17 & 22.4 & 21.6 & 16.4 & 7.9 \\
\hline 18 & 39.8 & 20.3 & 23.7 & 12.0 \\
\hline 19 & 43.5 & 21.8 & 26.4 & 11.0 \\
\hline 20 & 49.8 & 19.0 & 32.3 & 17.4 \\
\hline 21 & 56.4 & 17.9 & 48.2 & 16.7 \\
\hline 22 & $69.1^{*}$ & 18.4 & 63.5 & 11.4 \\
\hline
\end{tabular}

*No data on 11/29 at Station 826.

Table 13. Before and after plow-barge operations yield stress z-test results.

\begin{tabular}{|c|c|c|}
\hline Depth (ft) & $z$ Value & Probability (\%) \\
\hline \multicolumn{3}{|c|}{ Stations 756,762 , and 768} \\
\hline 16 & -0.99 & 68 \\
\hline 17 & -0.10 & 8 \\
\hline 18 & 1.35 & 82 \\
\hline 19 & 1.14 & 75 \\
\hline 20 & 1.32 & 81 \\
\hline 21 & 0.18 & 14 \\
\hline 22 & 1.31 & 81 \\
\hline \multicolumn{3}{|c|}{ Stations $780,784,788,792,796,800,804$, and 808} \\
\hline 16 & 1.44 & 85 \\
\hline 17 & 0.82 & 59 \\
\hline 18 & -0.11 & 9 \\
\hline 19 & -0.37 & 29 \\
\hline 20 & 0.41 & 32 \\
\hline 21 & 0.93 & 65 \\
\hline 22 & 1.54 & 88 \\
\hline \multicolumn{3}{|c|}{ Stations 820,826 , and 832} \\
\hline 16 & 1.01 & 69 \\
\hline 17 & 0.66 & 49 \\
\hline 18 & 1.79 & 93 \\
\hline 19 & 1.81 & 93 \\
\hline 20 & 1.89 & 94 \\
\hline 21 & 0.94 & 65 \\
\hline 22 & 0.63 & 47 \\
\hline
\end{tabular}


For Stations 756, 762, and 768, the bottom of the plow was at $19 \mathrm{ft}$ and primarily acted on the mud at depths of 16-19 ft. Table 11 shows that at depths 16 through $19 \mathrm{ft}$, the mean yield stresses were lower after the plowbarge operations than they were before the operations at 18 and $19 \mathrm{ft}$ and higher at 16 and $17 \mathrm{ft}$; however, the net reduction in mean yield stress for these four depths was 14.0 Pa. For Stations 780, 784, 788, 792, 796, 800, 804 , and 808, the plow was at $21 \mathrm{ft}$ and acted on depths $18-21 \mathrm{ft}$. Table 11 shows that at depths 20 and $21 \mathrm{ft}$, the mean yield stresses were lower after the plow-barge operations and higher after the operations at 18 and $19 \mathrm{ft}$. There was a net reduction in mean yield stress for all four depths of 9.7 Pa. For Stations 820, 826, and 832, the plow was at $22 \mathrm{ft}$ and acted on depths 19-22 ft. Table 12 shows that the mean yield stresses were lower after the plow-barge operations at all four depths, and the net reduction in mean yield stress was $48.4 \mathrm{~Pa}$.

Tables 14 through 20 give mean yield stresses at each depth for each station and show that at Stations 756, 762, and 768, the mean yield stresses decreased between 16 and $19 \mathrm{ft}$ in 7 out of 12 cases. Mean yield stress increased at Stations 756 and 768 at $16 \mathrm{ft}$, at Stations 762 and 768 at $17 \mathrm{ft}$, and at $19 \mathrm{ft}$ at Station 756. For Stations 780 through 808, Tables 18 through 19 show that the mean yield stresses decreased between 18 and 21 $\mathrm{ft}$ in 13 of 31 cases, the 18 increases in mean yield stress being at Stations 780, 792, and 808 at $18 \mathrm{ft}$; at Stations 780, 784, 788, 804, and 808 at $19 \mathrm{ft}$; at Stations 780, 788, 796, 804, and 808 at $20 \mathrm{ft}$; and at Stations 780, 788, 792, 804, and 808 at $21 \mathrm{ft}$. For Stations 820, 826, and 832, Tables 17 through 20 show mean yield stress decreases between 19 and $22 \mathrm{ft}$ in 10 of 12 cases. At station 832 at $21 \mathrm{ft}$, there was no change, and mean yield stress increased at Station 826 at $22 \mathrm{ft}$.

Since there are mean yield stress reduction probabilities over $75 \%$ at nine depths and the only depths that had an increase had probabilities of $68 \%$, $8 \%, 9 \%$, and $29 \%$ (Table 13), it cannot be ruled out that the plow-barge operations did reduce yield stress in some places. However, the results are very inconsistent. For example, at Stations 820, 826, and 832 (Tables 13), where the plow-barge was towed at $22 \mathrm{ft}$, there were reductions in mean yield stress at $19 \mathrm{ft}$ with a $93 \%$ probability and at $20 \mathrm{ft}$ with a $94 \%$ probability; however, at $18 \mathrm{ft}, 1 \mathrm{ft}$ above the plow, there was a reduction in mean yield stress, which also had a 93\% probability. At $22 \mathrm{ft}$, the depth of the bottom of the plow and at $21 \mathrm{ft}$ the probabilities of the decreases in yield stress were only $47 \%$ and $65 \%$. For stations 756,762 , and 768 where 
the plow was towed at $19 \mathrm{ft}$, the data results show increased yield stress at $16 \mathrm{ft}$ and $17 \mathrm{ft}$. The increase at $16 \mathrm{ft}$ had the highest probability of the four observed increases (i.e., 68\%).

Notes for Tables 14-21:

*No data on $11 / 29$.

${ }^{1}$ Measurement on 11/29 not included because it exceeded 3 standard deviations.

${ }^{2}$ Measurement on 12/4 not included because it exceeded 3 standard deviations.

3Measurements on 12/2 not included because they exceeded 3 standard deviations.

4Measurements on 12/3 not included because they exceeded 3 standard deviations.

Table 14. Mean yield stresses before and after plow-barge operations for the stations in Table 3 at a depth of $16 \mathrm{ft}$.

\begin{tabular}{|c|c|c|c|c|}
\hline \multirow{2}{*}{ Station } & \multicolumn{2}{|c|}{ Before Operations } & \multicolumn{2}{c|}{ After Operations } \\
\cline { 2 - 5 } & $\begin{array}{c}\text { Mean Yield } \\
\text { Stress }(\mathrm{Pa})\end{array}$ & $\begin{array}{c}\text { Standard } \\
\text { Deviation }(\mathrm{Pa})\end{array}$ & $\begin{array}{c}\text { Mean Yield } \\
\text { Stress (Pa) }\end{array}$ & $\begin{array}{c}\text { Standard } \\
\text { Deviation }(\mathrm{Pa})\end{array}$ \\
\hline 756 & $4.1^{*}$ & 1.6 & 8.5 & 13.5 \\
\hline 762 & 2.4 & 1.2 & 1.9 & 1.5 \\
\hline 768 & 3.4 & 2.9 & 6.6 & 7.2 \\
\hline 780 & 10.4 & NA & 10.7 & 6.6 \\
\hline 784 & 18.2 & NA & $7.8^{2}$ & 5.7 \\
\hline 788 & 9.6 & NA & 7.7 & 5.4 \\
\hline 792 & 5.6 & NA & 7.9 & 4.2 \\
\hline 796 & 20.5 & NA & 10.4 & 5.5 \\
\hline 800 & 38.9 & NA & 7.8 & 4.5 \\
\hline 804 & 12.0 & NA & 13.44 & 12.4 \\
\hline 808 & 10.6 & NA & 9.2 & 1.7 \\
\hline 820 & 6.6 & 6.5 & 6.9 & 5.3 \\
\hline 826 & 6.7 & 7.8 & 3.5 & 1.7 \\
\hline 832 & 2.9 & 3.0 & 1.1 & 0.4 \\
\hline
\end{tabular}


Table 15. Mean yield stresses before and after plow-barge operations for the stations in Table 3 at a depth of $17 \mathrm{ft}$.

\begin{tabular}{|c|c|c|c|c|}
\hline \multirow{2}{*}{$\begin{array}{c}\text { Depth } \\
(\mathrm{MLG} \mathrm{ft})\end{array}$} & \multicolumn{2}{|c|}{ Before Operations } & \multicolumn{2}{c|}{ After Operations } \\
\cline { 2 - 5 } Stress (Pa) & $\begin{array}{c}\text { Mean Yield } \\
\text { Deviation (Pa) }\end{array}$ & $\begin{array}{c}\text { Mean Yield } \\
\text { Stress (Pa) }\end{array}$ & $\begin{array}{c}\text { Standard } \\
\text { Deviation (Pa) }\end{array}$ \\
\hline 756 & 23.7 & 11.7 & 16.0 & 10.9 \\
\hline 762 & 14.6 & 2.7 & 18.2 & 15.2 \\
\hline 768 & 23.6 & 13.3 & 29.3 & 24.9 \\
\hline 780 & 12.4 & NA & 21.6 & 8.0 \\
\hline 784 & 26.0 & NA & 23.1 & 8.3 \\
\hline 788 & 19.5 & NA & 20.2 & 9.1 \\
\hline 792 & 16.0 & NA & 15.3 & 6.0 \\
\hline 796 & 16.0 & NA & 26.7 & 20.5 \\
\hline 800 & 58.5 & NA & 20.1 & 6.6 \\
\hline 804 & 29.2 & NA & 19.74 & 11.9 \\
\hline 808 & 22.1 & NA & 16.7 & 12.2 \\
\hline 820 & 10.4 & 9.4 & 15.5 & 4.0 \\
\hline 826 & 17.1 & 4.3 & 21.1 & 7.6 \\
\hline 832 & 13.8 & 9.8 & 12.6 & 10.1 \\
\hline
\end{tabular}

Table 16. Mean yield stresses before and after plow-barge operations for the stations in Table 3 at a depth of $18 \mathrm{ft}$.

\begin{tabular}{|c|c|c|c|c|}
\hline \multirow{2}{*}{$\begin{array}{c}\text { Depth } \\
(\mathrm{MLG} \text { ft) }\end{array}$} & \multicolumn{2}{|c|}{ Before Operations } & \multicolumn{2}{c|}{ After Operations } \\
\cline { 2 - 5 } & $\begin{array}{c}\text { Mean Yield } \\
\text { Stress (Pa) }\end{array}$ & $\begin{array}{c}\text { Standard } \\
\text { Deviation (Pa) }\end{array}$ & $\begin{array}{c}\text { Mean Yield } \\
\text { Stress (Pa) }\end{array}$ & $\begin{array}{c}\text { Standard } \\
\text { Deviation (Pa) }\end{array}$ \\
\hline 756 & 21.7 & 7.7 & 20.5 & 3.2 \\
\hline 762 & 32.5 & 15.7 & 21.1 & 9.4 \\
\hline 768 & 36.6 & 32.2 & 22.0 & 20.4 \\
\hline 780 & 22.6 & NA & 30.5 & 8.1 \\
\hline 784 & 30.4 & NA & 29.4 & 10.2 \\
\hline 788 & 30.6 & NA & 25.2 & 9.4 \\
\hline 792 & 15.1 & NA & 23.5 & 10.1 \\
\hline 796 & 33.1 & NA & 30.0 & 11.6 \\
\hline 800 & NA 1 & NA & 23.5 & 6.2 \\
\hline 804 & 44.2 & NA & 37.5 & 22.7 \\
\hline 808 & 15.8 & NA & 23.9 & 16.8 \\
\hline 820 & 36.2 & 40.3 & 20.2 & 8.7 \\
\hline 826 & 38.5 & 0.4 & 36.4 & 10.0 \\
\hline 832 & 36.8 & 20.4 & 14.5 & 2.6 \\
\hline
\end{tabular}


Table 17. Mean yield stresses before and after plow-barge operations for the stations in Table 3 at a depth of $19 \mathrm{ft}$.

\begin{tabular}{|c|c|c|c|c|}
\hline \multirow{2}{*}{$\begin{array}{c}\text { Depth } \\
(\mathrm{MLG} \mathrm{ft})\end{array}$} & \multicolumn{2}{|c|}{ Before Operations } & \multicolumn{2}{c|}{ After Operations } \\
\cline { 2 - 5 } Stress (Pa) & $\begin{array}{c}\text { Mean Yield } \\
\text { Deviation (Pa) }\end{array}$ & $\begin{array}{c}\text { Mean Yield } \\
\text { Stress (Pa) }\end{array}$ & $\begin{array}{c}\text { Standard } \\
\text { Deviation (Pa) }\end{array}$ \\
\hline 756 & 19.6 & 3.1 & 24.7 & 12.3 \\
\hline 762 & 28.0 & 13.4 & 19.0 & 5.6 \\
\hline 768 & 39.2 & 37.5 & 19.0 & 9.5 \\
\hline 780 & 16.9 & NA & 35.5 & 14.4 \\
\hline 784 & 22.6 & NA & 41.9 & 19.8 \\
\hline 788 & 19.7 & NA & 42.0 & 27.2 \\
\hline 792 & 27.8 & NA & 27.5 & 11.1 \\
\hline 796 & 49.6 & NA & 39.8 & 26.4 \\
\hline 800 & 94.4 & NA & 34.6 & 9.2 \\
\hline 804 & 26.0 & NA & 49.5 & 34.8 \\
\hline 808 & 14.0 & NA & 29.6 & 8.1 \\
\hline 820 & 48.0 & 40.0 & 22.1 & 6.9 \\
\hline 826 & 40.2 & 20.0 & 28.9 & 11.3 \\
\hline 832 & 42.2 & 17.8 & 28.3 & 15.1 \\
\hline
\end{tabular}

Table 18. Mean yield stresses before and after plow-barge operations for the stations in Table 3 at a depth of $20 \mathrm{ft}$.

\begin{tabular}{|c|c|c|c|c|}
\hline \multirow{2}{*}{$\begin{array}{c}\text { Depth } \\
\text { (MLG ft) }\end{array}$} & \multicolumn{2}{|c|}{ Before Operations } & \multicolumn{2}{c|}{ After Operations } \\
\cline { 2 - 5 } & $\begin{array}{c}\text { Mean Yield } \\
\text { Stress (Pa) }\end{array}$ & $\begin{array}{c}\text { Standard } \\
\text { Deviation (Pa) }\end{array}$ & $\begin{array}{c}\text { Mean Yield } \\
\text { Stress (Pa) }\end{array}$ & $\begin{array}{c}\text { Standard } \\
\text { Deviation (Pa) }\end{array}$ \\
\hline 756 & 22.5 & 5.3 & 16.0 & 3.8 \\
\hline 762 & 18.8 & 7.3 & 15.2 & 2.7 \\
\hline 768 & 36.5 & 43.5 & 18.0 & 9.8 \\
\hline 780 & 17.2 & NA & 46.8 & 26.2 \\
\hline 784 & 87.2 & NA & 57.2 & 21.5 \\
\hline 788 & 14.9 & NA & 38.1 & 18.2 \\
\hline 792 & 46.0 & NA & 23.7 & 10.8 \\
\hline 796 & 43.5 & NA & 46.5 & 24.4 \\
\hline 800 & 103.4 & NA & 33.7 & 6.7 \\
\hline 804 & 19.1 & NA & 42.2 & 19.4 \\
\hline 808 & 36.6 & NA & 40.5 & 9.1 \\
\hline 820 & 45.1 & 36.6 & 25.2 & 13.2 \\
\hline 826 & 57.1 & 2.6 & 32.2 & 4.1 \\
\hline 832 & 47.3 & 17.3 & 39.5 & 27.9 \\
\hline
\end{tabular}


Table 19. Mean yield stresses before and after plow-barge operations for the stations in Table 3 at a depth of $21 \mathrm{ft}$.

\begin{tabular}{|c|c|c|c|c|}
\hline \multirow{2}{*}{$\begin{array}{c}\text { Depth } \\
(\mathrm{MLG} \mathrm{ft})\end{array}$} & \multicolumn{2}{|c|}{ Before Operations } & \multicolumn{2}{c|}{ After Operations } \\
\cline { 2 - 5 } Stress (Pa) & $\begin{array}{c}\text { Mean Yield } \\
\text { Deviation (Pa) }\end{array}$ & $\begin{array}{c}\text { Mean Yield } \\
\text { Stress (Pa) }\end{array}$ & $\begin{array}{c}\text { Standard } \\
\text { Deviation (Pa) }\end{array}$ \\
\hline 756 & 29.8 & 6.0 & 18.7 & 7.8 \\
\hline 762 & 22.2 & 12.8 & 28.4 & 21.0 \\
\hline 768 & 39.2 & 36.2 & 39.4 & 20.9 \\
\hline 780 & 40.4 & NA & 49.5 & 23.6 \\
\hline 784 & 83.9 & NA & 48.7 & 24.3 \\
\hline 788 & 17.2 & NA & 35.8 & 9.3 \\
\hline 792 & 37.6 & NA & 41.3 & 7.9 \\
\hline 796 & 52.2 & NA & 43.9 & 20.0 \\
\hline 800 & 98.5 & NA & 30.93 & 5.8 \\
\hline 804 & 44.4 & NA & 46.0 & 18.3 \\
\hline 808 & 51.4 & NA & 54.2 & 13.5 \\
\hline 820 & 51.4 & 34.7 & 46.8 & 10.6 \\
\hline 826 & 62.7 & 13.2 & 42.6 & 7.1 \\
\hline 832 & 55.1 & 9.8 & 55.1 & 27.4 \\
\hline
\end{tabular}

Table 20. Mean yield stresses before and after plow-barge operations for the stations in Table 3 at a depth of $22 \mathrm{ft}$.

\begin{tabular}{|c|c|c|c|c|}
\hline \multirow{2}{*}{$\begin{array}{c}\text { Depth } \\
(\text { MLG ft) }\end{array}$} & \multicolumn{2}{|c|}{ Before Operations } & \multicolumn{2}{c|}{ After Operations } \\
\cline { 2 - 5 } & $\begin{array}{c}\text { Mean Yield } \\
\text { Stress (Pa) }\end{array}$ & $\begin{array}{c}\text { Standard } \\
\text { Deviation (Pa) }\end{array}$ & $\begin{array}{c}\text { Mean Yield } \\
\text { Stress (Pa) }\end{array}$ & $\begin{array}{c}\text { Standard } \\
\text { Deviation (Pa) }\end{array}$ \\
\hline 756 & 34.6 & 12.9 & 19.5 & 5.5 \\
\hline 762 & 29.9 & 9.3 & 32.3 & 8.4 \\
\hline 768 & $61.0 *$ & 18.4 & 40.5 & 23.4 \\
\hline 780 & 42.7 & NA & 66.1 & 10.1 \\
\hline 784 & 88.3 & NA & 60.7 & 24.7 \\
\hline 788 & 55.3 & NA & 58.5 & 22.9 \\
\hline 792 & 57.5 & NA & 55.7 & 4.5 \\
\hline 796 & 88.9 & NA & 53.8 & 24.6 \\
\hline 800 & 143.4 & NA & 56.13 & 6.4 \\
\hline 804 & 66.5 & NA & 58.1 & 14.1 \\
\hline 808 & 73.0 & NA & 65.4 & 7.2 \\
\hline 820 & 75.5 & 18.2 & 58.6 & 9.9 \\
\hline 826 & $44.8 *$ & NA & 62.5 & 10.3 \\
\hline 832 & 74.9 & 17.0 & 69.3 & 14.0 \\
\hline
\end{tabular}


The second type of yield-stress analysis in which entire profiles were excluded if they appeared to be shifted is illustrated in Figures 10 through 21. Figures 10, 11, and 12 show yield-stress profiles, grouped by stations and therefore grouped by plow-barge operations, from before the operations. They were plotted and analyzed using the 5-point running vertical averages from each before-operations survey, at each station. The running averages calculated at each depth where data existed were placed in $0.25 \mathrm{ft}$ depth bins according to their depth, and the measurements in each bin were averaged to produce single average values at $0.25 \mathrm{ft}$ intervals, starting at $15.75 \mathrm{ft}$ and going down to $22 \mathrm{ft}$. This was done to make comparisons between profiles at consistent depth intervals. In the figures, the profiles that appear to be shifted are marked with asterisks. The after-operations profiles were averaged in the same way as the beforeoperations data and are shown in Figures 13, 14, and 15. The shifted profiles are also marked with asterisks in these figures.

Figure 10. Before plow-barge operations Rheotune yield-stress profiles at Stations 756,762 , and 768.

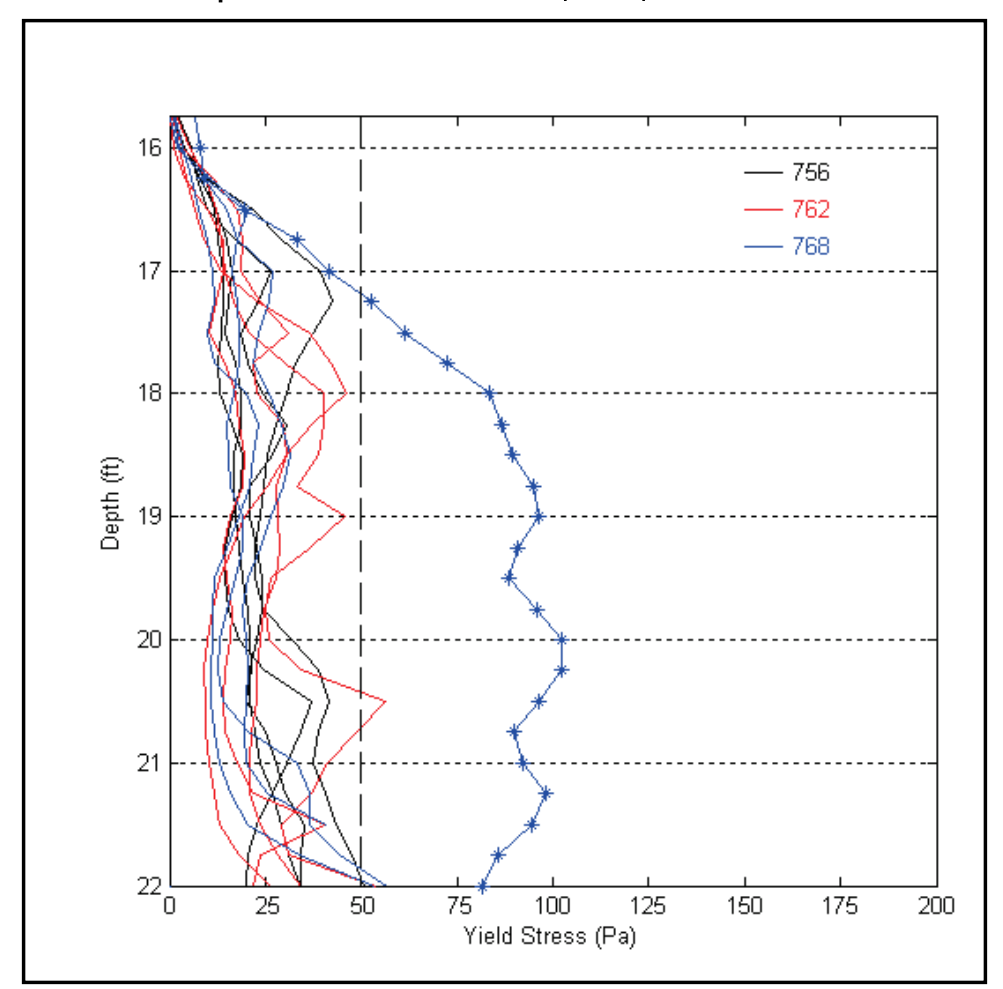


Figure 11. Before plow-barge operations Rheotune yield-stress profiles at Stations $780-808$.

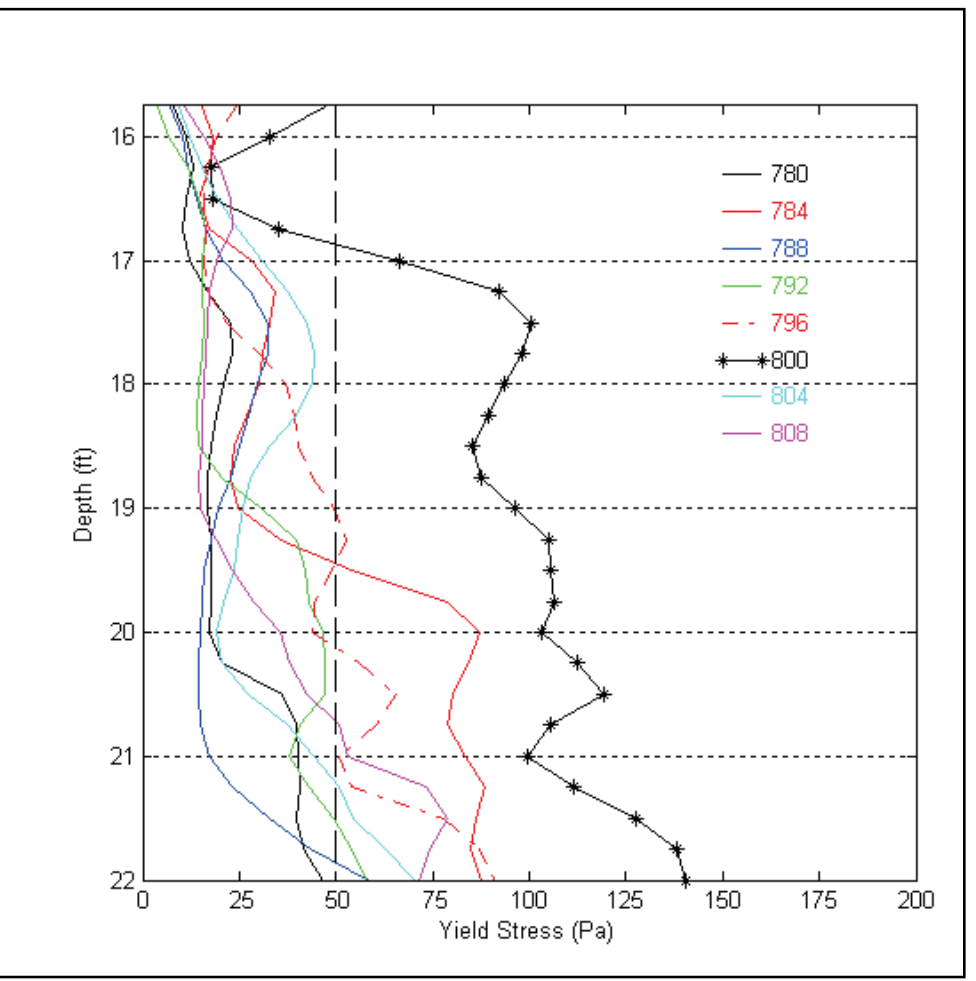

Figure 12. Before plow-barge operations Rheotune yield-stress profiles at Stations 820,826 , and 832.

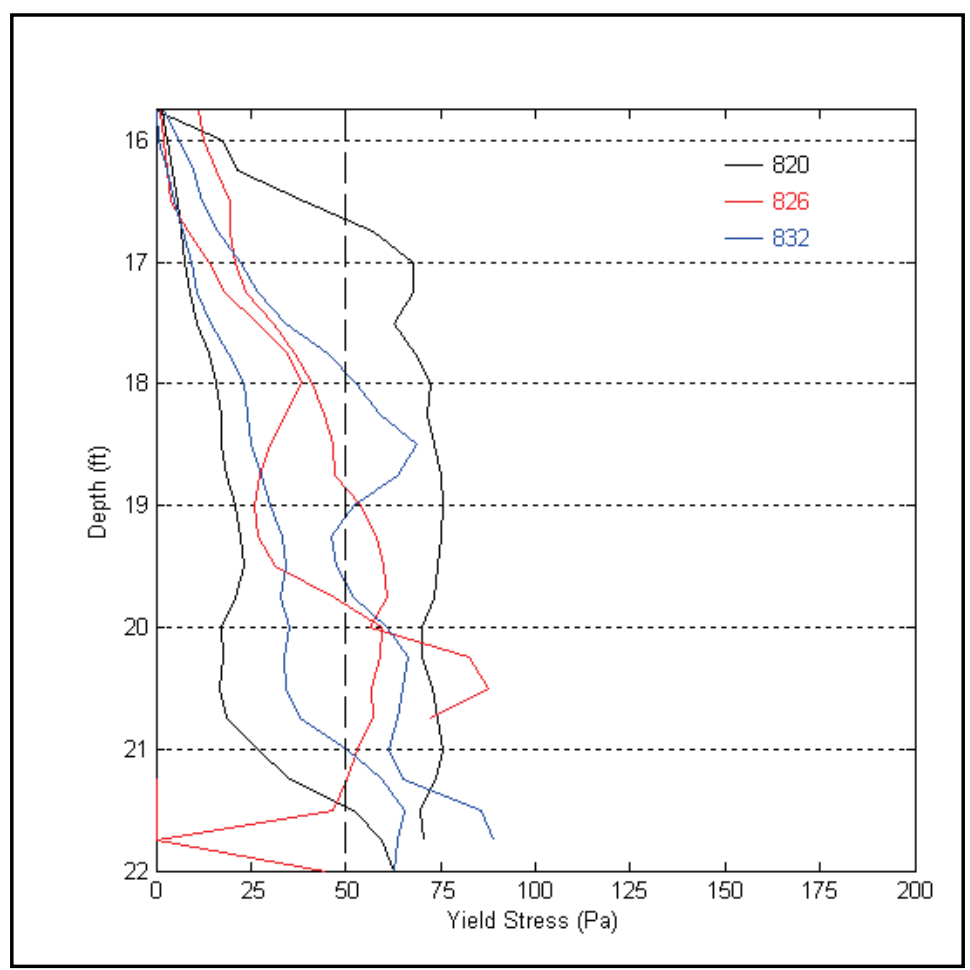


Figure 13. After plow-barge operations Rheotune yield-stress profiles at Stations 756,762 , and 768.

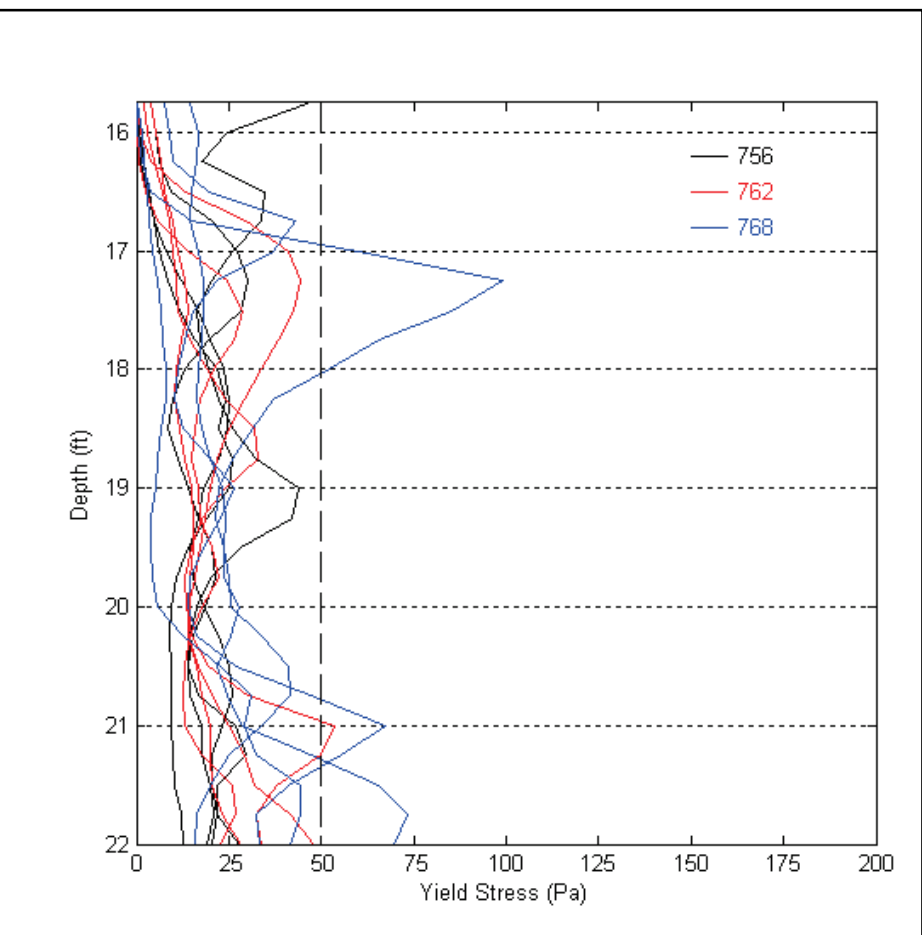

Figure 14. After plow-barge operations Rheotune yield-stress profiles at Stations $780-820$.

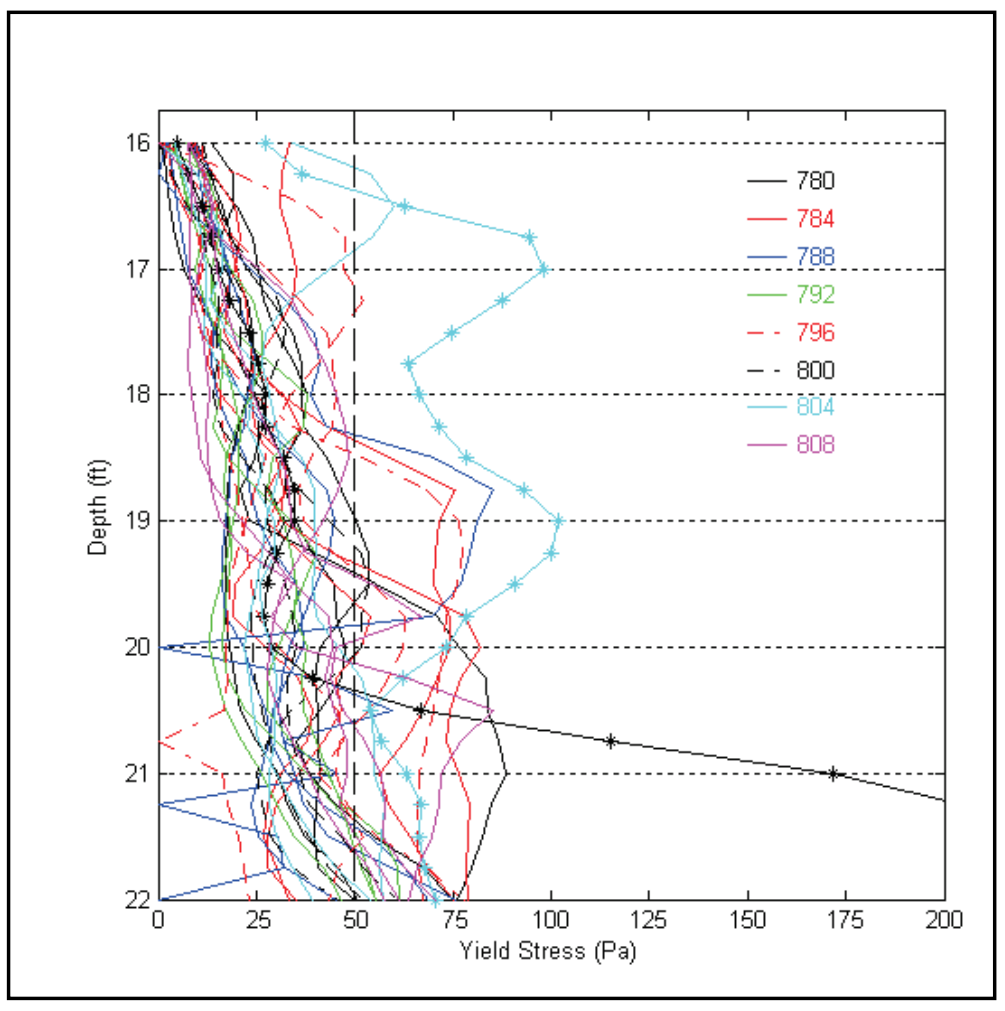


Figure 15. After plow-barge operations Rheotune yield-stress profiles at Stations 820,826 , and 832.

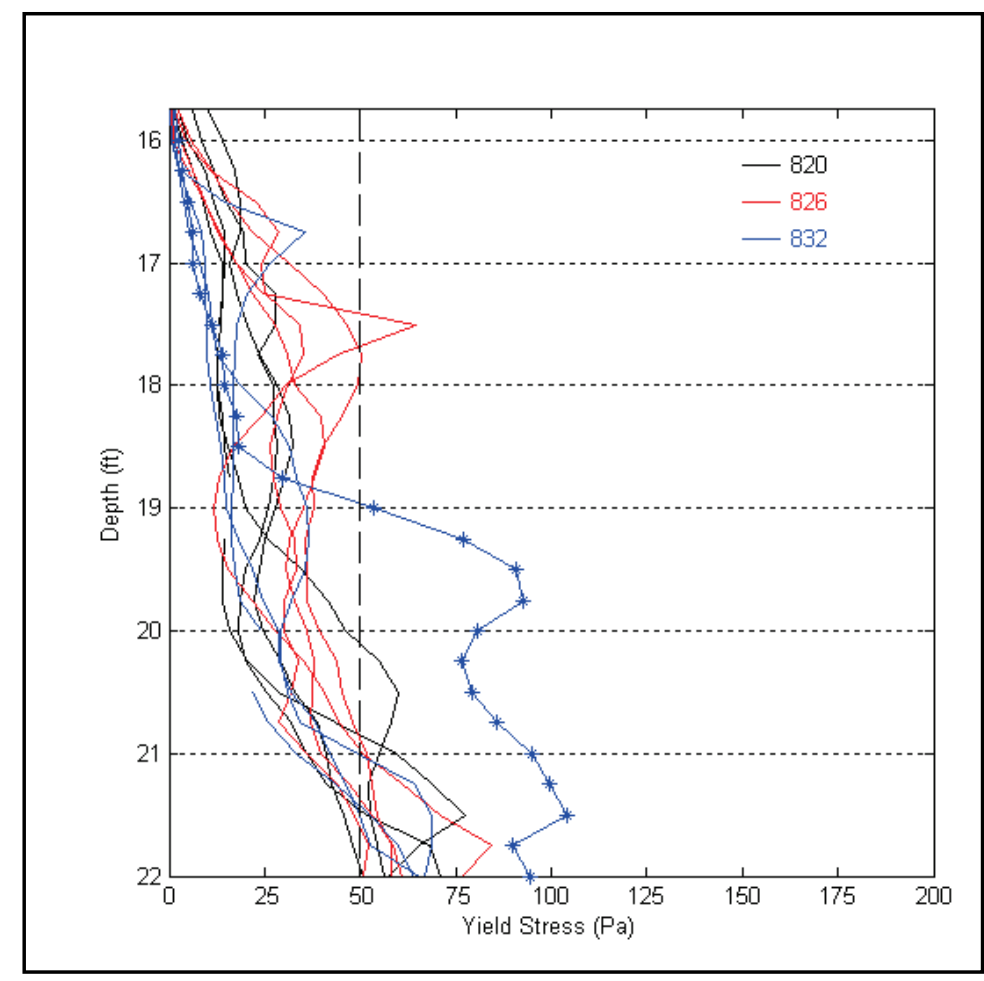

Figure 16. Before (-) and after (-*) plow-barge operations average Rheotune yield-stress profiles at Stations 756,762 , and 768.

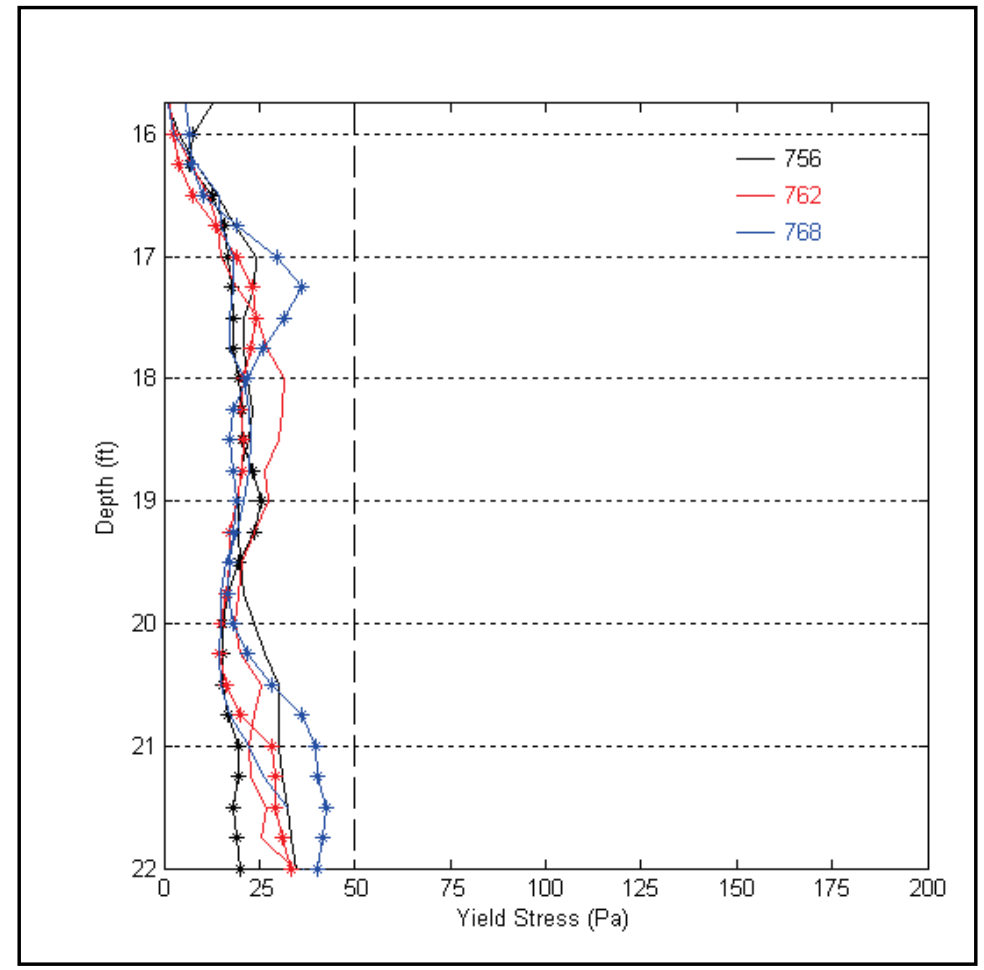


Figure 17. Before (-) and after (-*) plow-barge operations average Rheotune yield-stress profiles at Stations $780-808$.

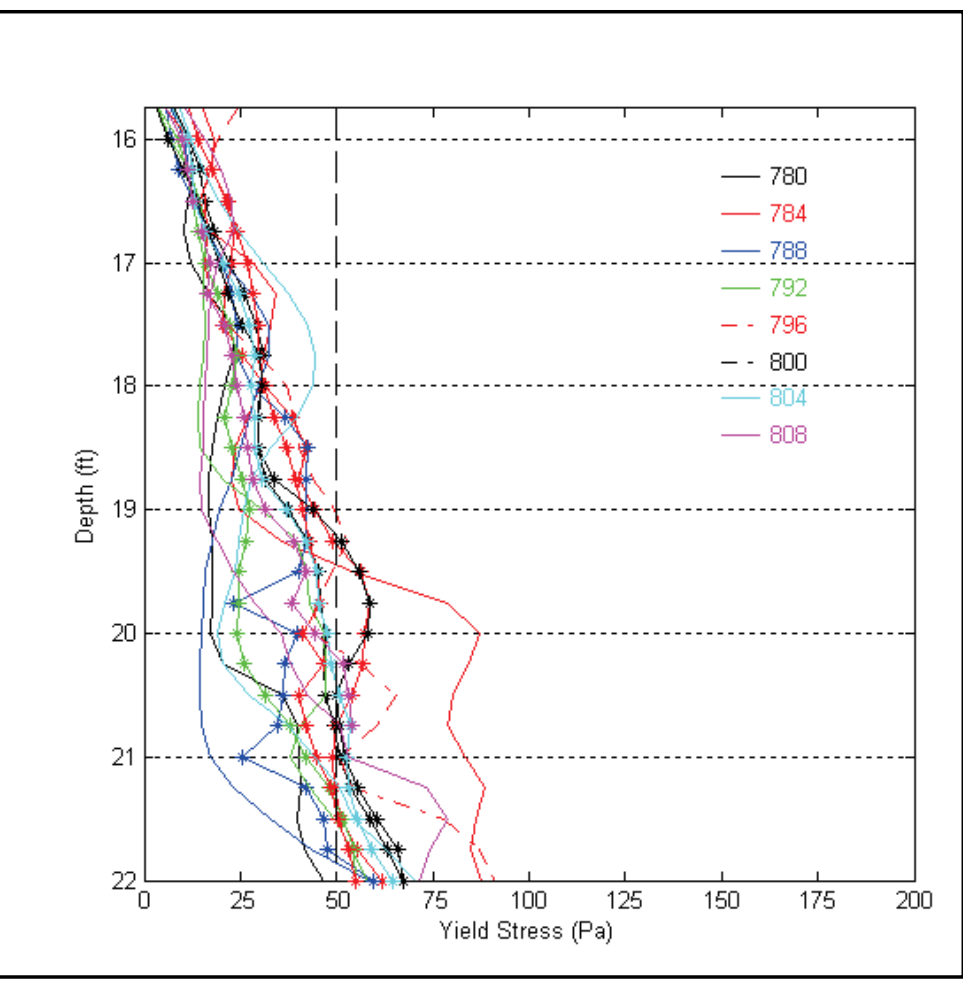

Figure 18. Before (-) and after (-*) plow-barge operations average Rheotune yield-stress profiles at Stations 820 , 826 , and 832.

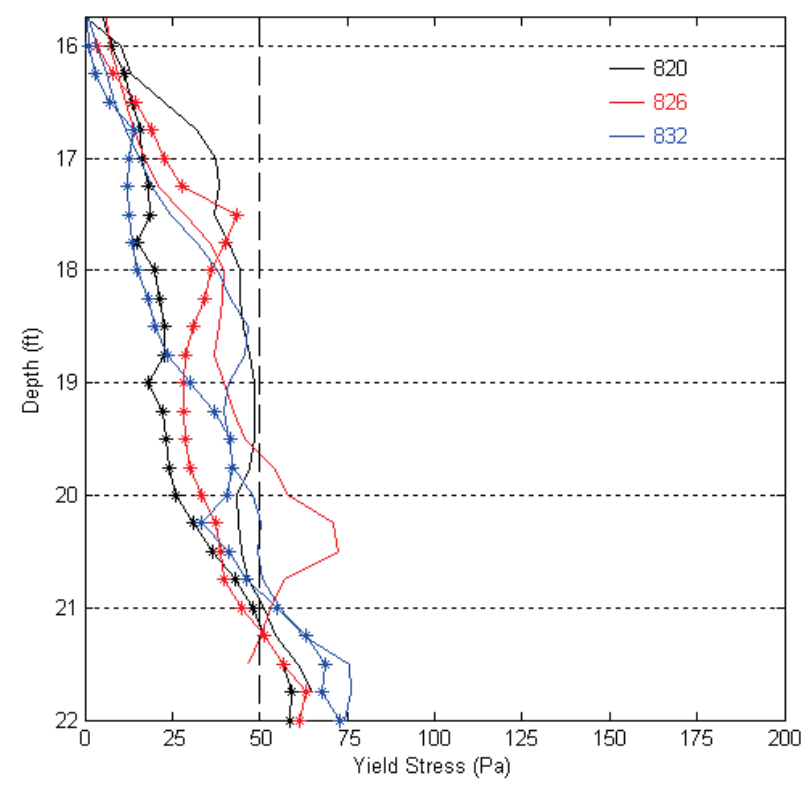


Figure 19. Difference between the average before and after average plow-barge operations profiles at Stations 756,762 , and 768.

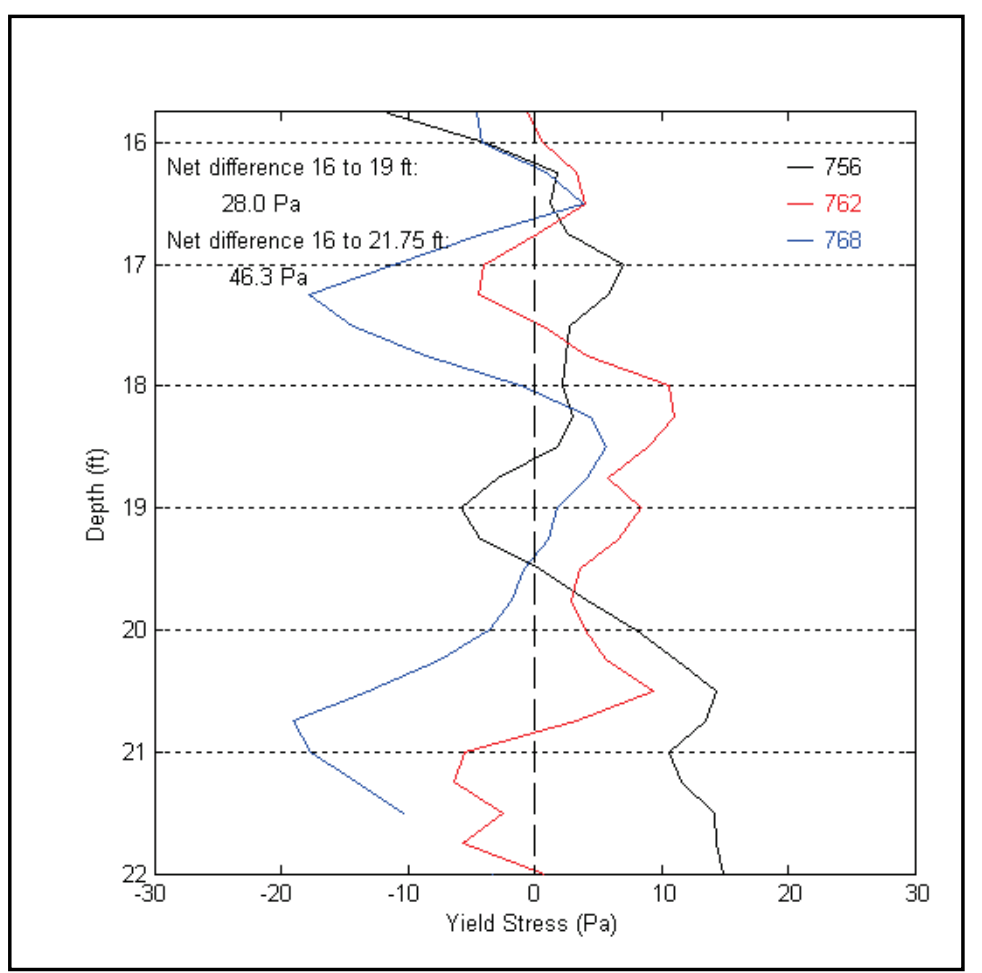

Figure 20. Difference between the average before and after average plow-barge operations profiles at Stations 780-808.

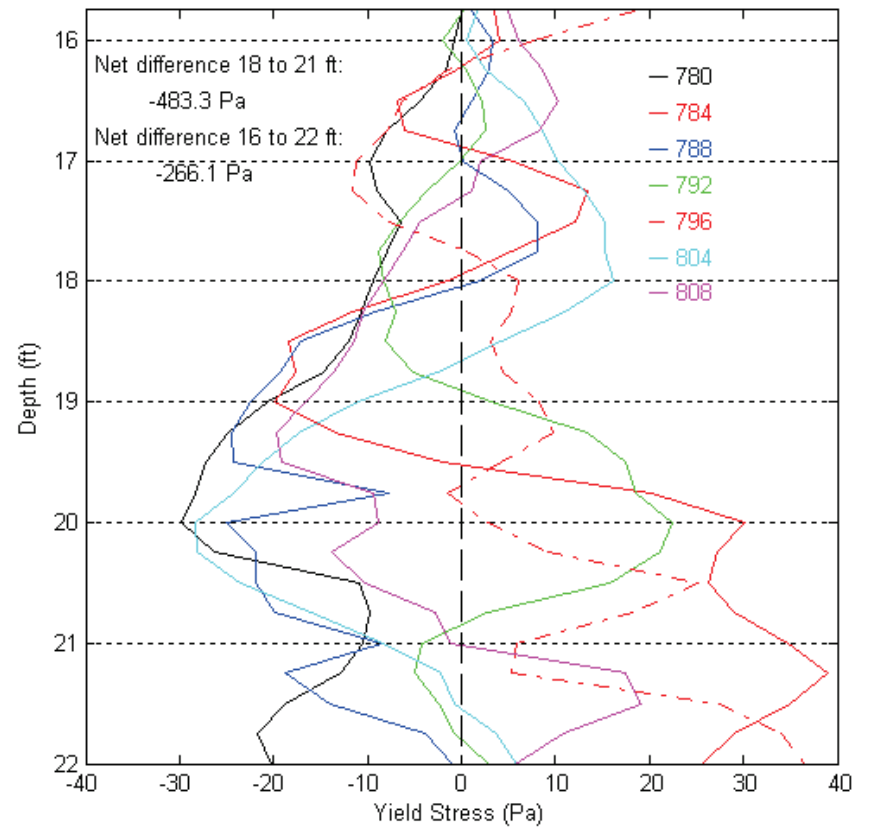


Figure 21. Difference between the average before and after average plow-barge operations profiles at Stations 820 , 826 , and 832.

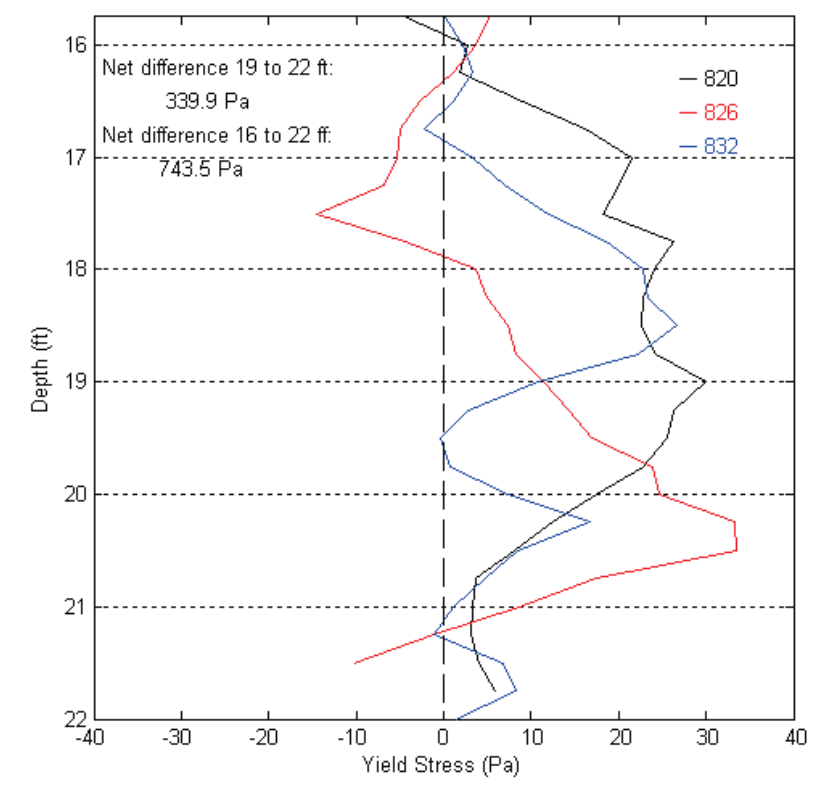

The other method to analyze the profiles was to average the profiles that were not excluded at each station, for the before- and after-operations surveys. For example, at Station 762 there were four surveys conducted before the plow barge operations on 29 November 2011 through 2 December 2011. None were excluded, so at each $0.25 \mathrm{ft}$ interval an average was calculated from the four values at the same 0.25-interval depths, from each of the four surveys.

The results are shown in Figures 16, 17, and 18. In these figures, the afteroperations average profiles are marked with asterisks. The differences between the before- and after-operations profiles are shown in Figures 19, 20, and 21. Any changes in the yield stresses resulting from the plow-barge operations would be evident. In these figures, a positive difference means that the yield stress was lower after the plow-barge operation than it was before the operation.

Analyzing the data by this method produces results that differ somewhat from the first method. For example, Table 17 shows a decrease in mean yield stress at $18 \mathrm{ft}$ at Station 768 , from 36.6 Pa before plow-barge operations to 22.0 Pa after plow-barge operations. However, Figure 19 shows a small increase in mean yield stress for Station 768 at $18 \mathrm{ft}$. This is 
because in the first method a yield stress of $83.6 \mathrm{~Pa}$ was measured on 2 December 2011. This before-operations measurement was not excluded in the first method of analysis because it was less than three times the standard deviation (i.e., 86.2 Pa, Table 10). In this analysis, the profile that produced the $83.6 \mathrm{~Pa}$ value was excluded because it appeared to be shifted (Figure 10).

Figure 19 shows that the net difference in yield stress from before to after plow-barge operations at Stations 756, 762, and 768 was a decrease of 28.o Pa from 16 to $19 \mathrm{ft}$ where the plow was towed and $46.3 \mathrm{~Pa}$ over the whole profile from 16 to $22 \mathrm{ft}$. Figure 20 shows that at Stations 780 through 808, there was a net increase in yield stress from 18 to $21 \mathrm{ft}$ of 483.3 $\mathrm{Pa}$ where the plow was towed and a net increase in yield stress of 266.1 $\mathrm{Pa}$ for the entire profile. In Figure 21, the plow was towed between 19 and $22 \mathrm{ft}$ at Stations 820, 826, and 832, and there was a net decrease in yield stress in this region of $339.9 \mathrm{~Pa}$. Over the entire profile there was a net decrease of $743.5 \mathrm{~Pa}$ at these stations.

Since there were net decreases in yield stress over the range of depths that the plow was towed for two of three plow-barge operations (Stations 756768 , and 820-832), it cannot be entirely ruled out that the operations did, and are capable of, reducing the overall yield stress. However, the relatively large increases in yield stress observed at Stations 780 through 808 over the range of depths that the plow was towed stands out as an obvious inconsistency.

\section{SILAS data}

SILAS data collected from the TECHE's echosounder system were analyzed to acoustically measure various density horizons. Figures 22, 23, and 24 show the SILAS survey transect along the channel centerline. In Figure 22, the black line denotes the $1.300 \mathrm{~g} / \mathrm{cm}^{3}$ density horizon surveyed 11 November 2011, and the red trace represents the $1.300 \mathrm{~g} / \mathrm{cm}^{3}$ horizon surveyed 4 December 2011. The plot graphically illustrates the dispersion, or variability, of the pre- and post-drag density values quantified in the previous Rheotune data analysis sections. Visual comparison of these two lines may provide insight to the fluid mud's reconsolidation characteristics on a temporal scale. For Test 3 (Stations 756-768, bottom, right-hand portion of transect in the figure), the post-drag (red) trace in Figure 22 is consistently deeper than the pre-drag (black) trace in comparison to the rest of the survey transect. This may be due to the fact that Test Area 3 was 
dragged (finished $0530 \mathrm{hr}$ on 3 December 2011) just the day before it was surveyed on 4 December 2011. In comparison, the pre- and post-drag (black and red) traces in Test Section 1 (Stations 780-808), dragged 30 November 2011 (finished at $1810 \mathrm{hrs),} \mathrm{are} \mathrm{closer} \mathrm{together} \mathrm{and} \mathrm{overlap}$ more often, potentially indicating that the fluid mud had consolidated more over the 4-day interval than it did in Test Area 3 in 1 day. However, Test Section 3 was dragged with the bottom of the bedleveler at $19 \mathrm{ft}$ while the other two test areas (shown in the upper portion of the transect in the figure) were dragged with the bedleveler at 21 and $22 \mathrm{ft}$. This may be a factor that could affect this interpretation.

Figure 23 shows the pre- (brown trace) and post-drag (orange trace) $1.250 \mathrm{~g} / \mathrm{cm}^{3}$ density horizons along the survey transect. Within the context of the entire transect, these traces also illustrate the density value variability observed in Figure 22 and to a lesser degree, the fluid mud spatial re-consolidation interpretation between Test Areas 1 and Test Sections 2 and 3 that were previously discussed. Figure 24 shows the spatial relationship between the $1.250 \mathrm{~g} / \mathrm{cm}^{3}$ and $1.300 \mathrm{~g} / \mathrm{cm}^{3}$ density horizons as surveyed on 29 November 2011 and 4 December 2011. Over most of the survey transect, they track each other in their vertical excursions and maintain an approximate $2 \mathrm{ft}$ vertical separation. 
Figure 22. SILAS acoustically measured horizons along centerline of ABC. Black trace $1.300 \mathrm{~g} / \mathrm{cm}^{3}$ horizon surveyed 11 November 2011 . Red trace $1.300 \mathrm{~g} /$ figure $\mathrm{cm}^{3}$ horizon surveyed 4 December 2011.
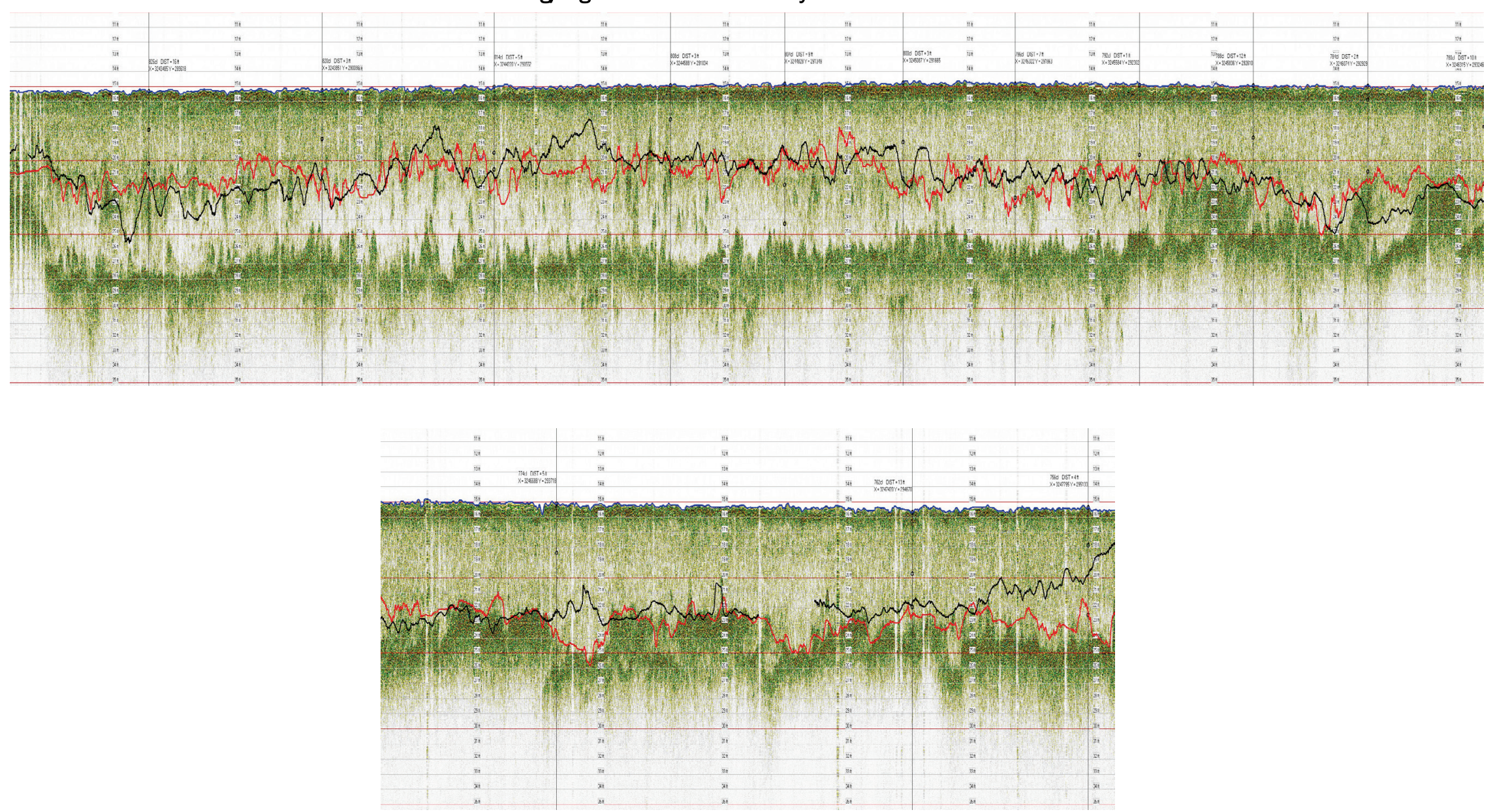
Figure 23. SILAS acoustically measured horizons along centerline of ABC. Brown trace $1.250 \mathrm{~g} / \mathrm{cm}^{3}$ horizon surveyed 29 November 2011 . Orange trace $1.250 \mathrm{~g} / \mathrm{cm}^{3}$ horizon surveyed 4 December 2011.
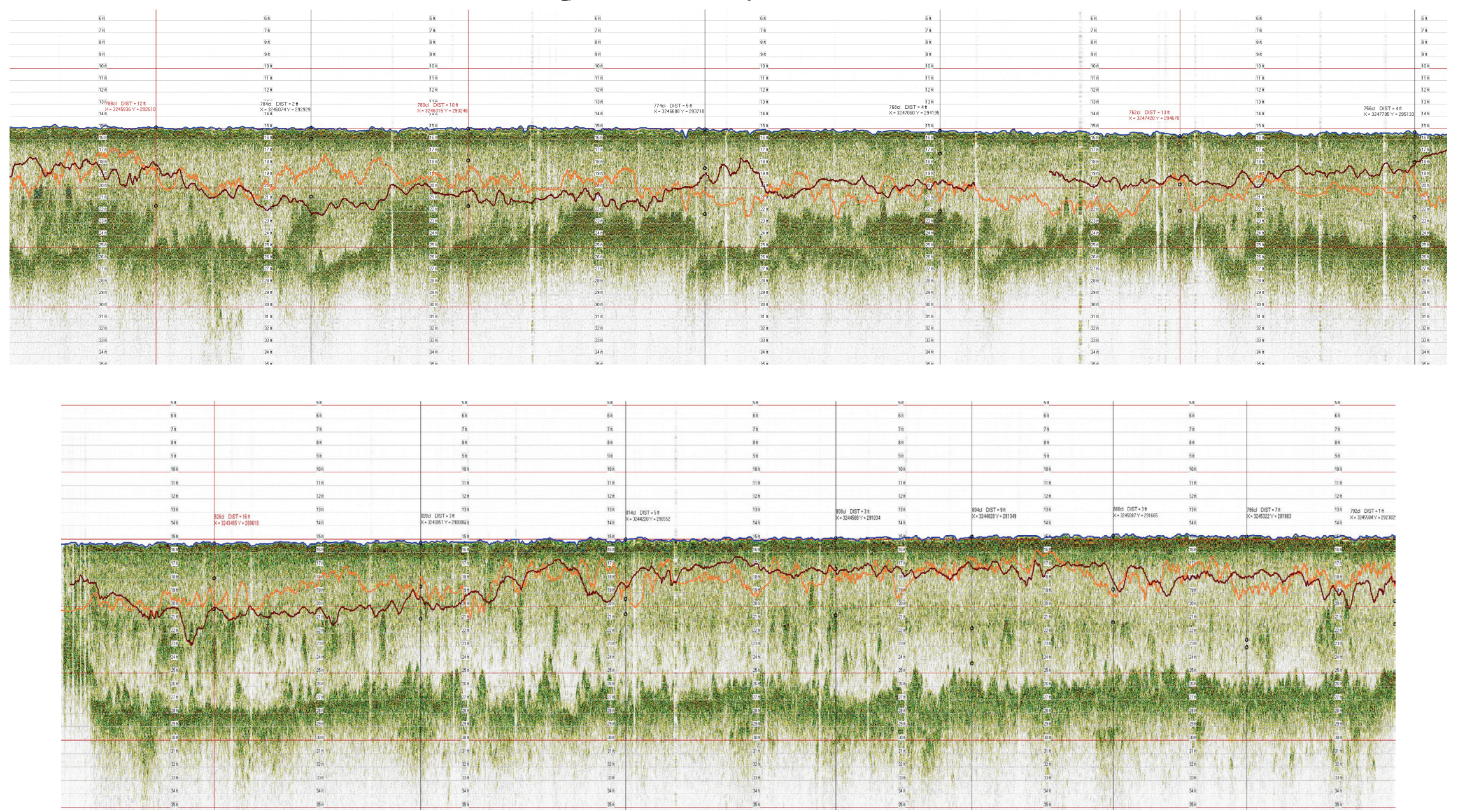
Figure 24. SILAS acoustically measured horizons down centerline of ABC. Orange trace is $1.250 \mathrm{~g} / \mathrm{cm}^{3}$ horizon, and red trace is $1.300 \mathrm{~g} / \mathrm{cm}^{3} \mathrm{horizon}$
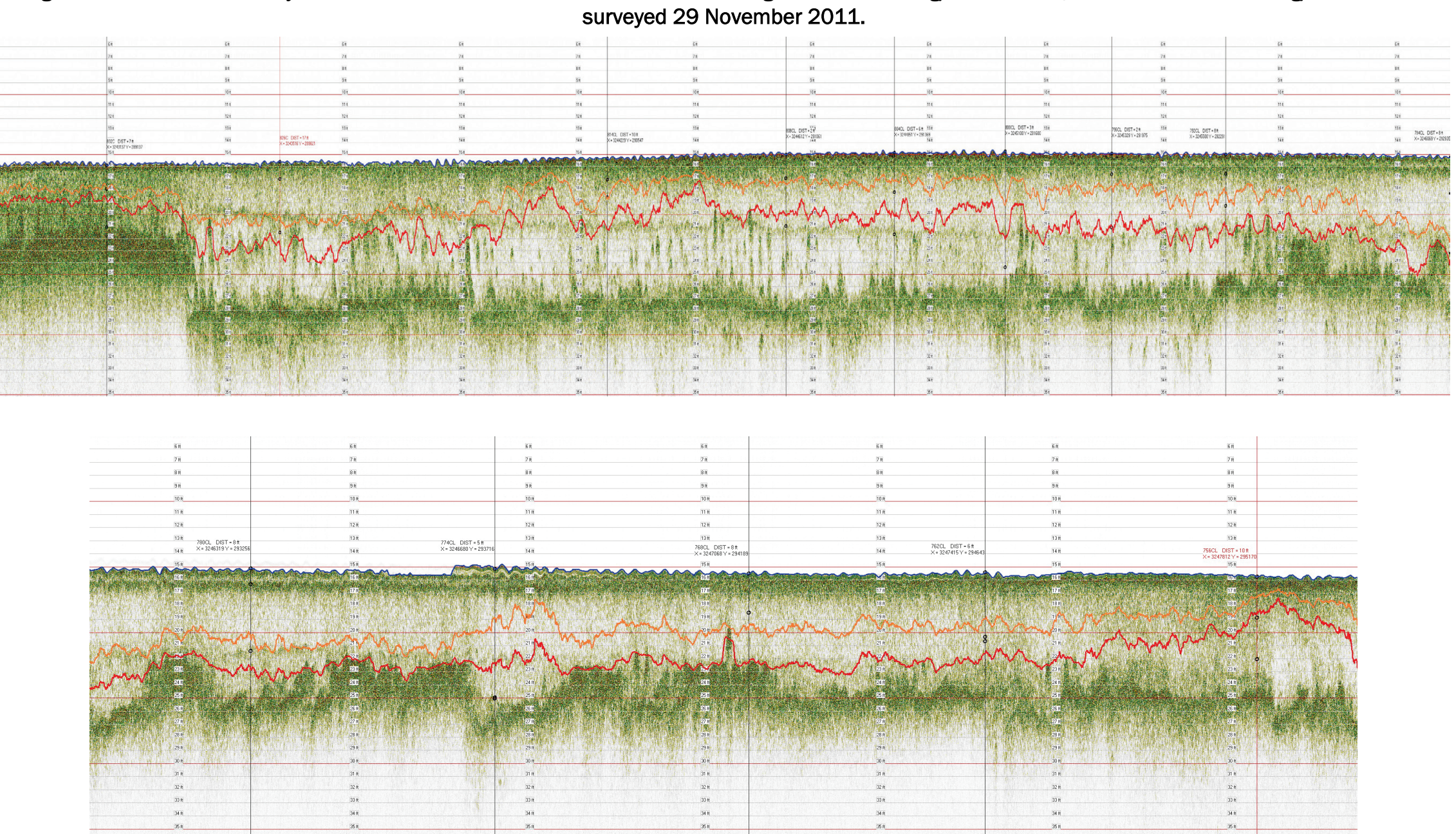


\section{Discussion}

This study was undertaken with the goal of proving a technology that could be applied to the $\mathrm{ABC}$ to easily and economically lengthen the time between conventional navigation dredging of the channel. It was based on the known potential for in situ conditioning of bottom fluid-mud sediments to break down inter-floc bonds and lower densities and yield strengths, thereby facilitating ship passage. The proposed method of conditioning was dragging a large steel beam (a bedleveler) through the fluid mud using a push-barge and tug. The towing operations were conducted without significant problems. Ship traffic in the channel was essentially nonexistent during the study, and no significant wave or currents were observed.

To evaluate the effect of the bedleveler operations on the channel fluid mud, a Stema Systems survey system consisting of a Rheotune and SILAS was used to measure fluid-mud densities and yield stresses before and after the plow-barge operations. CHL has conducted laboratory and field tests of the ability of the Rheotune to measure sediment densities and has concluded that with calibrations using sediments from the area in which the measurements are conducted (as was done for this study), the instrument can be relied on to produce density measurements that are sufficiently accurate to determine changes in sediment densities that would be significant in terms of channel navigability. The system's ability to measure yield-stress changes has not been verified by CHL, but it has been determined to be affective in other non-Corps operations via unpublished commercial surveys.

The data produced by the Stema System were analyzed by two methods that were capable of revealing significant effects from the plow-barge operations on the sediment properties. In regards to density, the plowbarge operations seem to have had no effect or an extremely limited effect over a short duration. Both types of Rheotune analysis lead to the same basic conclusions in regards to yield stresses. It cannot be ruled out that the plow-barge operations had an effect on yield stresses, but the measured decreases were so inconsistent that naturally occurring changes or some other factors had a larger effect. A check of ship traffic in the area 
during the time covered by the surveys indicates that was not a factor in possible changes in bottom characteristics. What other factors might have contributed to the variability of the density and yield stress measurements (including the possibility of instrument noise) are unknown. Neither analysis shows a region where the bedleveler was towed that there were decreases in yield stress at all stations, for all $3 \mathrm{ft}$ of bedleveler depth. The results of the analysis show that the plow-barge operations did not effectively decrease yield stress in the fluid mud. 


\section{Conclusions}

Plow-barge operations, consisting of dragging a large steel beam through fluid mud in the $\mathrm{ABC}$, were conducted to demonstrate the potential for using the method to condition the bottom sediments and improve the navigability of the Channel. Fluid mud densities and yield stresses were measured before and after the plow-barge operations, using a Stema Survey system. The data were analyzed by two methods to determine the potential variance in errors, neither of which demonstrated a change in these sediment properties that could be navigationally significant. The results of the study show that the plow-barge operations did not effectively decrease yield stresses and densities of the fluid mud. Therefore, the use of this method to lengthen the time between conventional dredging of the channel was determined to be ineffective. 


\section{References}

Kirby, R. 2011. Minimising harbor siltation-findings of PIANIC Working Group 43. Ocean Dynamics: Theoretical, Computational and Observational Oceanography 61:233-244.

U.S. Army Corps of Engineers (USACE). 2015. Dredging and dredged material management. Engineer Manual 1110-2-5025. Headquarters, Washington, DC. http://www.publications.usace.army.mil/Portals/76/Publications/EngineerManuals/EM_11102-5025.pdf

Wurpts, R. W., and N. Greiser. 2007. Monitoring and dredging technology in muddy layers. In Proceedings of World Dredging Congress (WODCON) XVIII, Lake Buena Vista Florida. https://westerndredging.org/index.php/woda-conferencepresentations/category/63-session-6a-survey-and-positioning-equipment 


\section{Appendix A: $1.300 \mathrm{~g} / \mathrm{cm}^{3}$ and 50 Pa Depths}

The depths in Table A-1 are (for Density, Den) the shallowest depth ( $\mathrm{ft}$ ) where a Density of $1.300 \mathrm{~g} / \mathrm{cm}^{3}$ was measured (unless otherwise indicated) and (for Yield Stress, YS) the shallowest depth where a Yield Stress of 50 Pa was measured.

Table A-1. Shallowest depth (ft) where Density (Den) of $1.300 \mathrm{~g} / \mathrm{cm}^{3}$ and Yield Stress (YS) of $50 \mathrm{~Pa}$ were measured (unless otherwise indicated).

\begin{tabular}{|c|c|c|c|c|c|c|c|c|c|c|}
\hline \multirow{2}{*}{ Station } & \multicolumn{2}{|c|}{$11 / 29 / 2011$} & \multicolumn{2}{|c|}{$11 / 30 / 2011$} & \multicolumn{2}{c|}{$12 / 1 / 2011$} & \multicolumn{2}{c|}{$12 / 2 / 2011$} & \multicolumn{2}{|c|}{$12 / 3 / 2011$} \\
\cline { 2 - 11 } & Den & YS & Den & YS & Den & YS & Den & YS & Den & YS \\
\hline 756 & 22.4 & 21.8 & 23.1 & 23.0 & 23.0 & 22.2 & 22.5 & 22.7 & 22.1 & 23.6 \\
\hline 762 & 20.9 & 17.9 & 22.1 & 19.0 & 22.3 & 21.4 & 22.0 & 22.3 & 22.3 & 22.8 \\
\hline 768 & $18.5^{*}$ & 21.8 & $21.2^{*}$ & 21.9 & $18.2^{*}$ & 21.9 & $17.0 *$ & 17.1 & $17.6 *$ & 21.4 \\
\hline 780 & 21.1 & 22.1 & 21.3 & 18.8 & 22.0 & 21.5 & 21.6 & 18.5 & 22.1 & 24.6 \\
\hline 784 & 22.9 & 19.5 & 21.1 & 22.6 & 21.5 & 19.1 & 25.0 & 19.1 & 21.7 & 23.1 \\
\hline 788 & 21.6 & 21.8 & 21.9 & 16.6 & 22.2 & 21.9 & 21.3 & 21.4 & 21.6 & 18.2 \\
\hline 792 & 18.9 & 20.5 & 17.3 & 17.6 & 20.5 & 21.3 & 21.1 & 21.3 & 21.5 & 22.0 \\
\hline 796 & 20.8 & 19.0 & 21.3 & 17.0 & 21.4 & 20.3 & 22.2 & 18.2 & 21.7 & 16.5 \\
\hline 800 & $24.3 *$ & 15.6 & $17.0 *$ & 16.6 & $18.5 *$ & 19.0 & $17.9 *$ & 20.1 & $18.2 *$ & 21.2 \\
\hline 804 & 21.3 & 21.1 & 20.9 & 17.2 & 21.4 & 23.7 & 20.1 & 19.9 & 21.0 & 15.9 \\
\hline 808 & 20.6 & 20.7 & 21.1 & 20.5 & 20.5 & 19.2 & 20.7 & 20.4 & 21.2 & 18.1 \\
\hline 820 & 19.4 & 16.7 & 19.2 & 21.5 & 20.1 & 21.5 & 20.0 & 20.1 & 20.5 & 20.9 \\
\hline 826 & 20.8 & 21.0 & 19.9 & 19.8 & 21.2 & 21.1 & 20.1 & 21.3 & 15.8 & 17.5 \\
\hline 832 & 20.2 & 17.8 & 20.1 & 21.0 & 21.4 & 21.0 & 20.2 & 21.2 & 20.5 & 21.4 \\
\hline
\end{tabular}

Profiles where a $1.300 \mathrm{~g} / \mathrm{cm}^{3}$ density was not reached are marked with the greatest density measured as follows: $* 1.250 \mathrm{~g} / \mathrm{cm}^{3}, 11.290 \mathrm{~g} / \mathrm{cm}^{3}$. 
Table A-1. (concluded)

\begin{tabular}{|c|c|c|c|c|c|c|c|c|c|c|}
\hline \multirow{2}{*}{ Station } & \multicolumn{2}{|c|}{$12 / 4 / 2011$} & \multicolumn{2}{|c|}{$12 / 5 / 2011$} & \multicolumn{2}{c|}{$12 / 8 / 2011$} & \multicolumn{2}{c|}{$12 / 13 / 2011$} & \multicolumn{2}{|c|}{$1 / 5 / 2011$} \\
\cline { 2 - 11 } & Den & YS & Den & YS & Den & YS & Den & YS & Den & YS \\
\hline 756 & 23.1 & 23.8 & 23.0 & 23.0 & 21.1 & 15.8 & 22.6 & 21.3 & 23.7 & 17.1 \\
\hline 762 & 22.3 & 23.0 & 23.0 & 23.0 & 21.7 & 20.9 & 22.4 & 22.6 & 21.5 & 21.7 \\
\hline 768 & 22.4 & 22.4 & $18.4 *$ & 17.0 & $17.5^{*}$ & 16.7 & $19.2^{*}$ & 22.0 & $17.9 *$ & 21.7 \\
\hline 780 & 22.0 & 22.1 & 21.2 & 18.7 & 20.8 & 23.0 & 21.4 & 22.0 & 17.7 & 17.6 \\
\hline 784 & 21.4 & 19.3 & 21.8 & 21.4 & 21.6 & 21.8 & 21.1 & 21.2 & 20.8 & 20.9 \\
\hline 788 & 22.2 & 22.4 & 22.5 & 18.4 & 21.6 & 19.6 & 22.1 & 21.5 & 24.6 & 18.0 \\
\hline 792 & 22.0 & 22.2 & 21.2 & 18.7 & 21.4 & 22.4 & 21.7 & 21.8 & 21.9 & 18.2 \\
\hline 796 & 23.8 & 20.2 & 22.1 & 16.5 & 15.7 & 18.0 & 21.6 & 22.4 & 21.8 & 21.9 \\
\hline 800 & $19.5 *$ & 22.9 & $16.6 *$ & 21.5 & $24.0 *$ & 17.8 & $18.9 *$ & 22.2 & $16.7 *$ & 21.5 \\
\hline 804 & 25.0 & 17.1 & 21.4 & 19.0 & 20.8 & 20.6 & 27.0 & 17.9 & 19.0 & 18.6 \\
\hline 808 & 21.1 & 21.1 & 21.5 & 21.3 & 22.0 & 17.1 & 21.3 & 20.8 & 19.2 & 20.7 \\
\hline 820 & 21.5 & 22.9 & 21.7 & 18.0 & 20.8 & 20.6 & 20.4 & 21.6 & $20.0^{2}$ & 21.7 \\
\hline 826 & 20.9 & 18.8 & 20.5 & 22.0 & 22.1 & 21.4 & 21.0 & 21.1 & 20.3 & 16.3 \\
\hline 832 & 19.9 & 20.2 & 23.0 & 18.5 & 21.0 & 19.0 & 20.4 & 19.7 & 19.5 & 19.2 \\
\hline
\end{tabular}

Profiles where a $1.300 \mathrm{~g} / \mathrm{cm}^{3}$ density was not reached are marked with the greatest density measured as follows: $* 1.250 \mathrm{~g} / \mathrm{cm}^{3}, 21.278 \mathrm{~g} / \mathrm{cm}^{3}$. 


\section{Appendix B: Station Density vs. Days Plots}

Appendix B displays $1.300 \mathrm{~g} / \mathrm{cm}^{3}$ density depths vs. time (days), with bedleveler completion day and depth extent indicated by rectangles. The cross-hatched vertical rectangle on these plots illustrates the day that the bedleveler completed the respective pass (from Table 1), and its vertical dimension ( $3 \mathrm{ft}$ ) illustrates the bedleveler's depth extent in relation to the depths at which $1.300 \mathrm{~g} / \mathrm{cm}^{3}$ was measured.

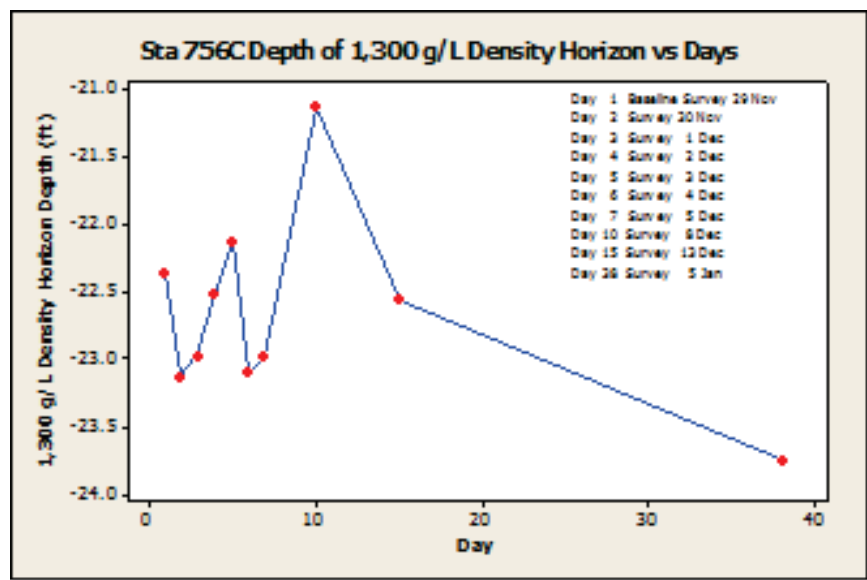

Station $756 C$

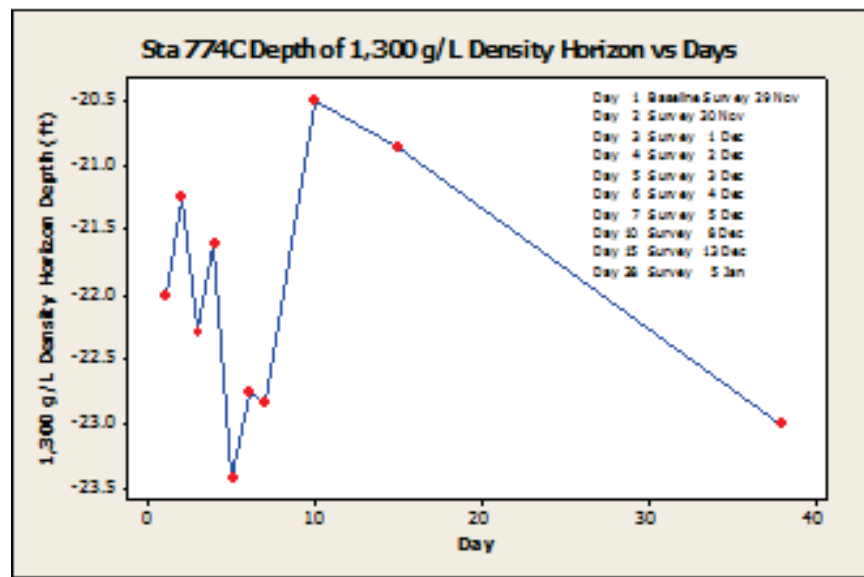

Station $774 \mathrm{C}$

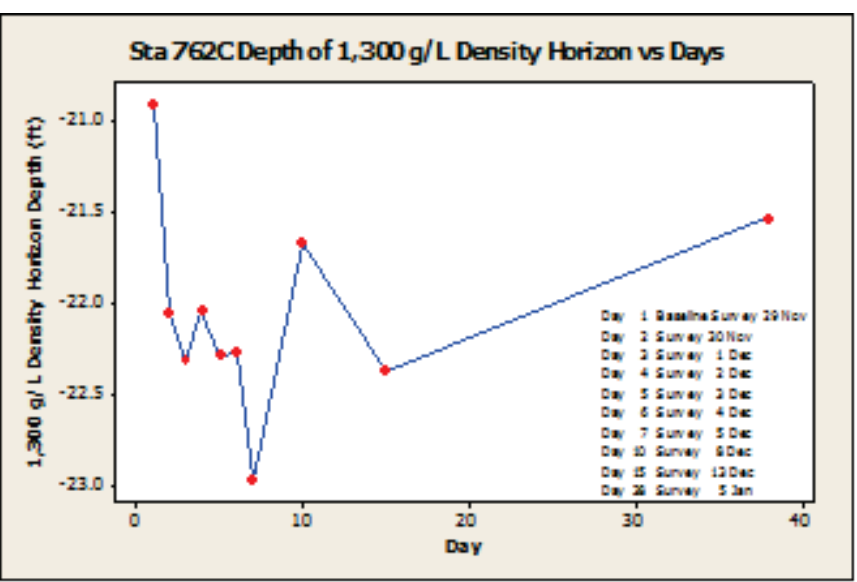

Station $762 \mathrm{C}$

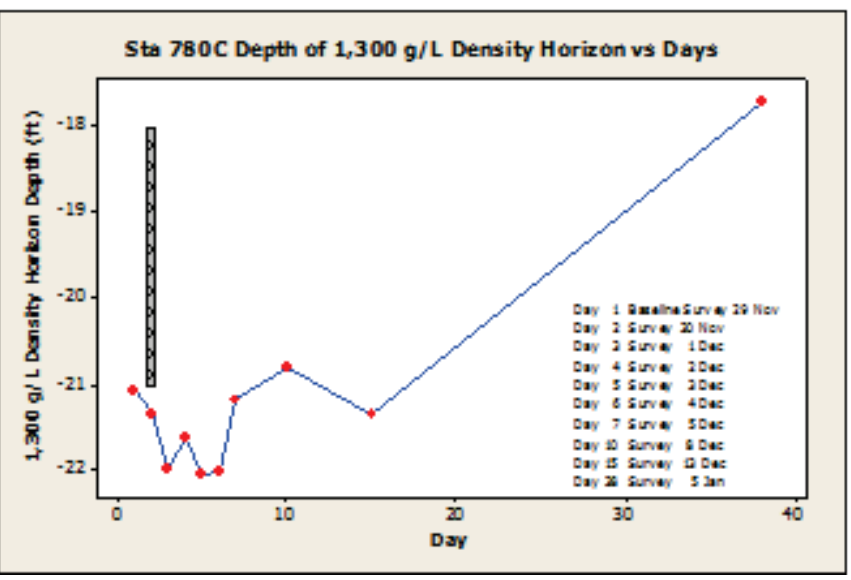

Station $780 \mathrm{C}$ 


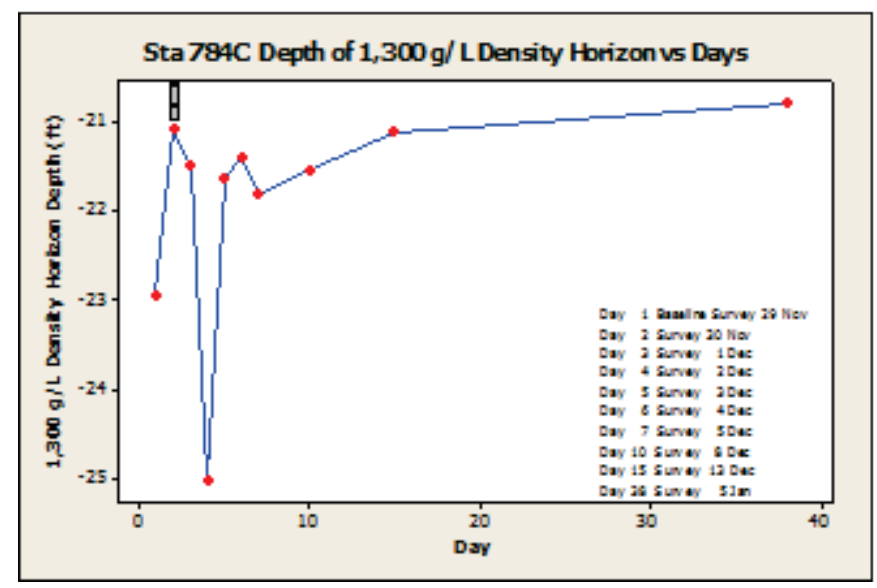

Station $784 \mathrm{C}$

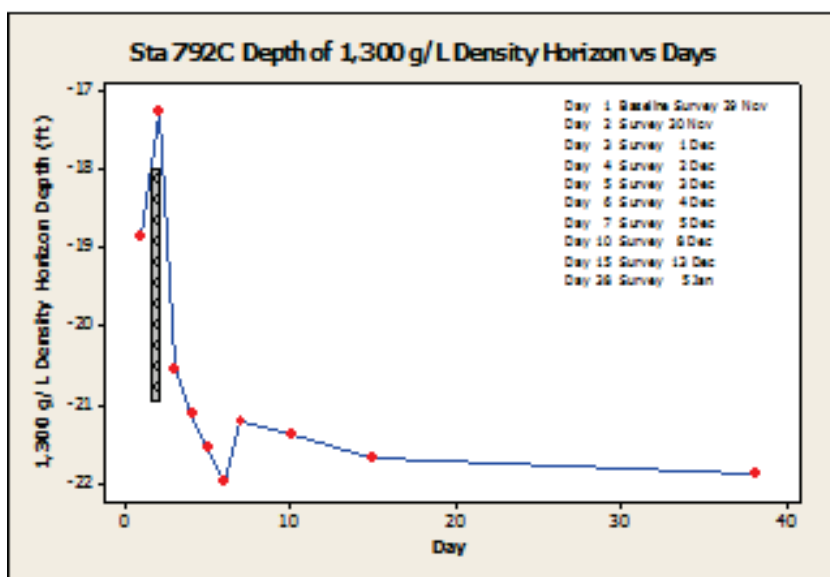

Station $792 \mathrm{C}$

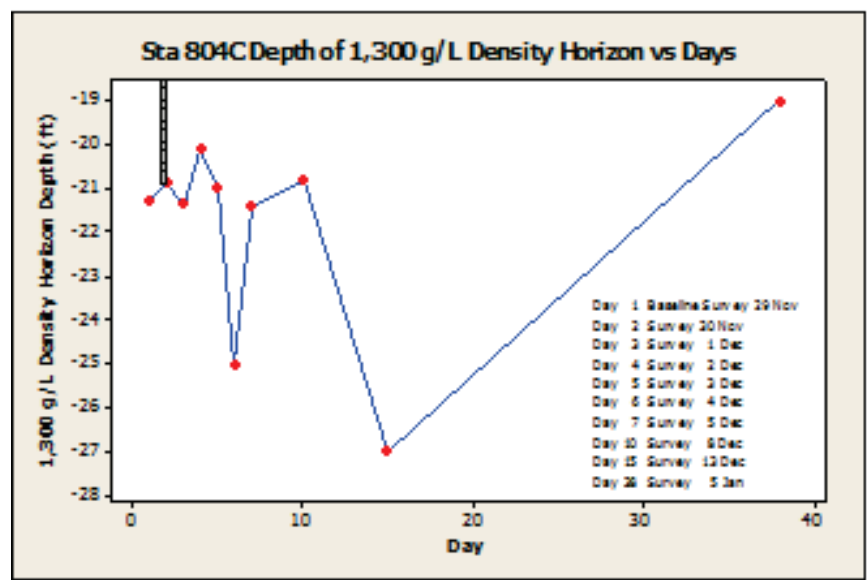

Station 804C

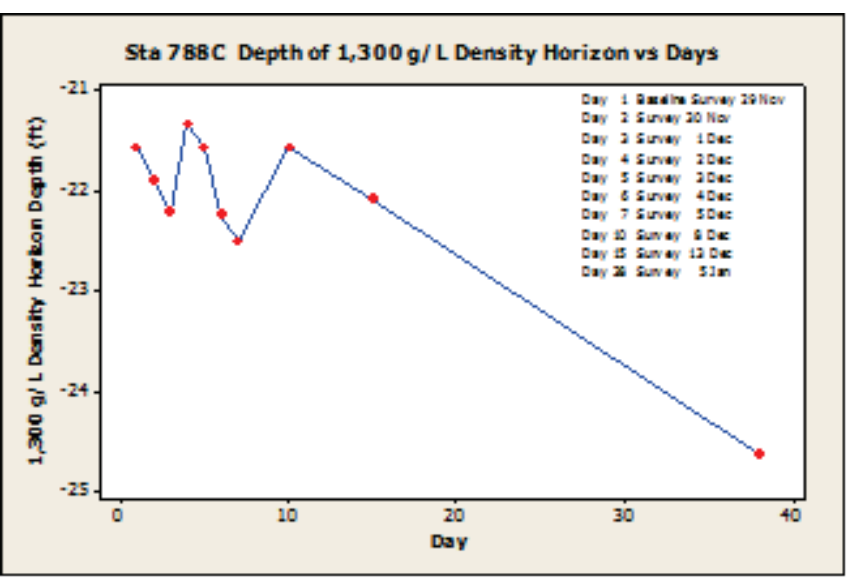

Station $788 \mathrm{C}$

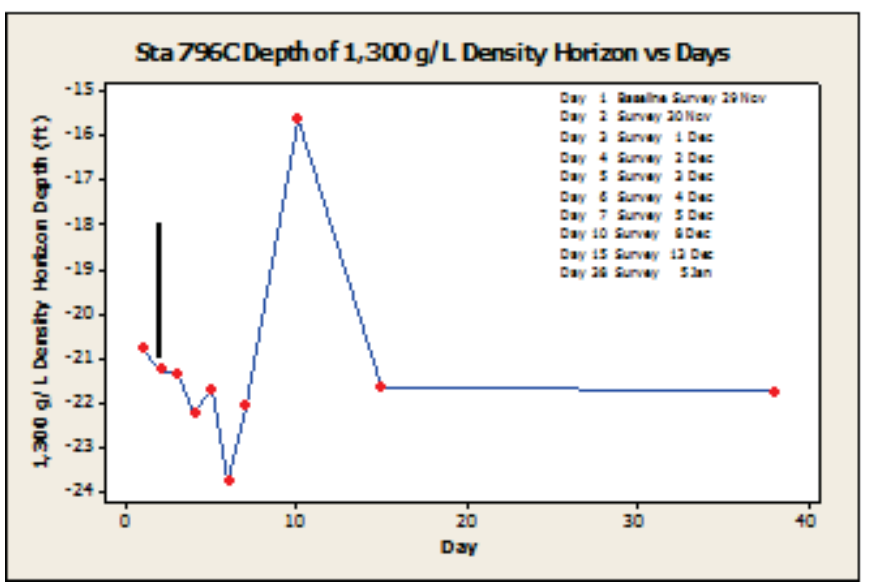

Station $796 C$

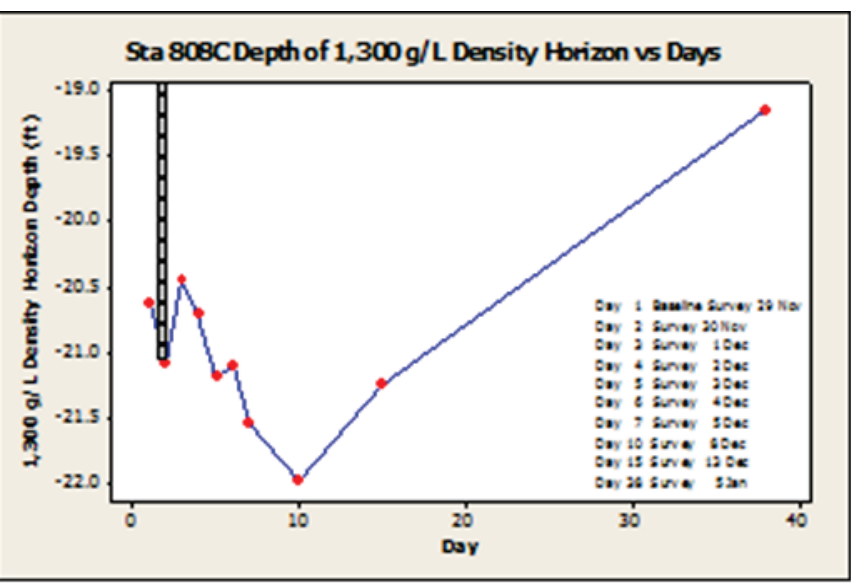

Station 808C 


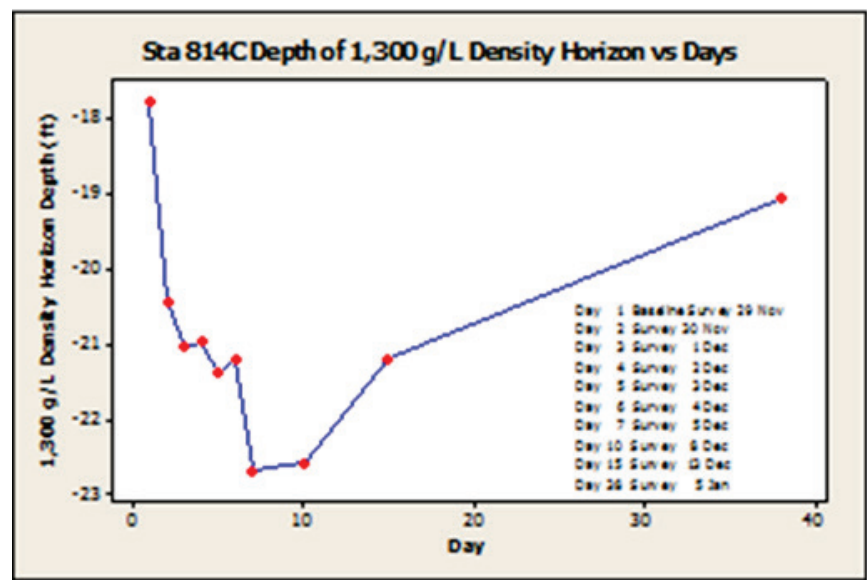

Station $814 \mathrm{C}$

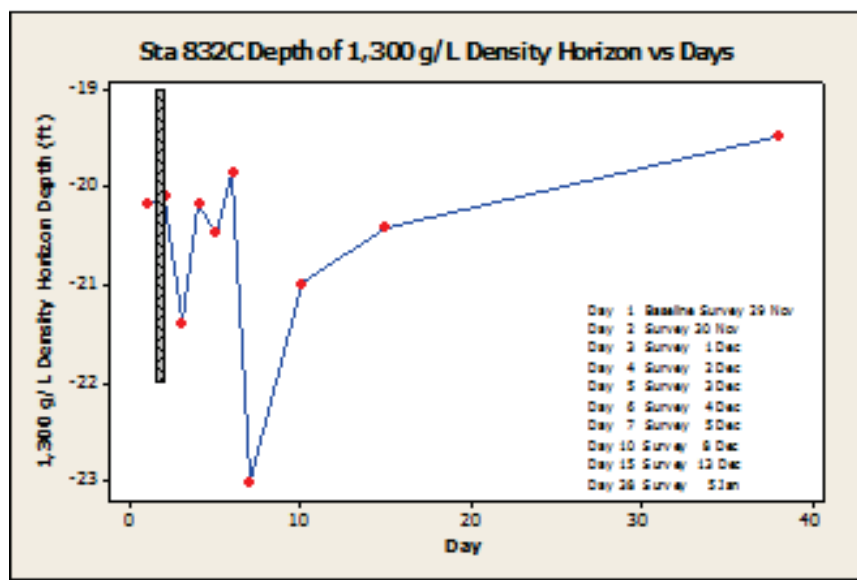

Station 826C

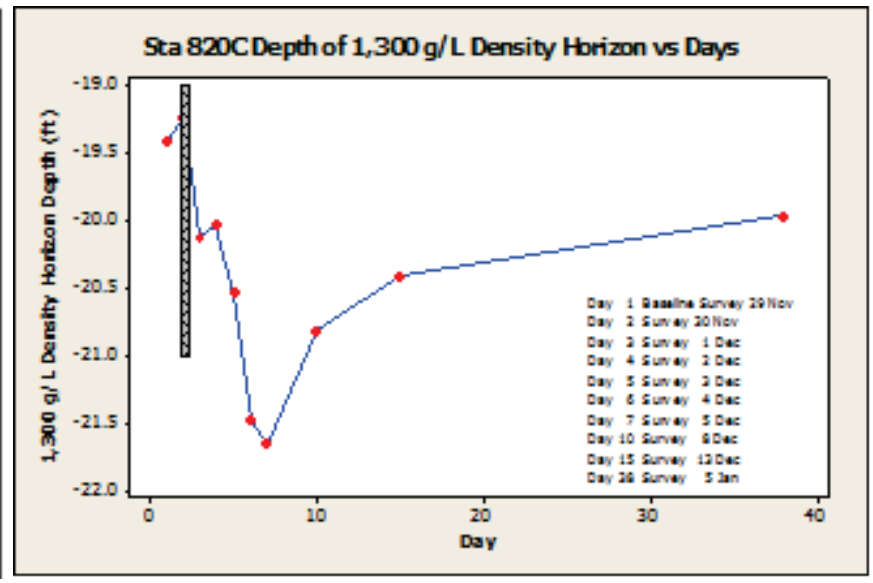

Station 820C

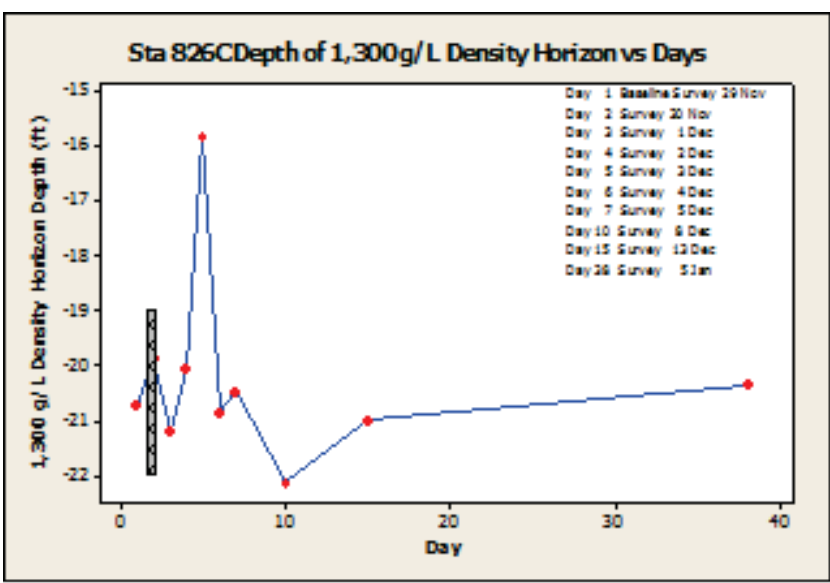

Station $832 \mathrm{C}$ 


\section{Appendix C: Station Yield Stress vs. Days Plots}

Appendix C displays 50 Pa yield stress depths vs. time (days) with bedleveler completion day and depth extent indicated by rectangles. The crosshatched vertical rectangle on these plots illustrates the day that the bedleveler completed the respective pass (from Table 1), and its vertical dimension ( $3 \mathrm{ft}$ ) illustrates the bedleveler's depth extent in relation to the depths at which 50 Pa was measured.

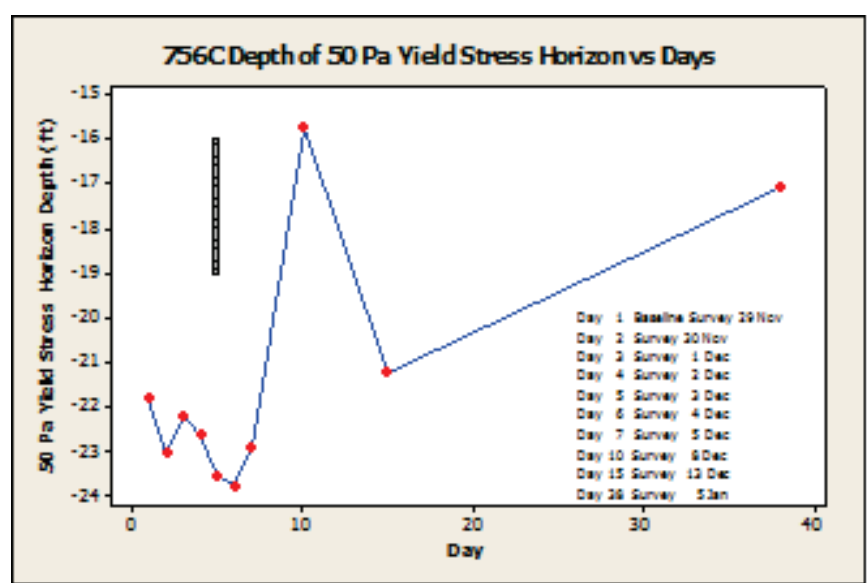

Station $756 \mathrm{C}$

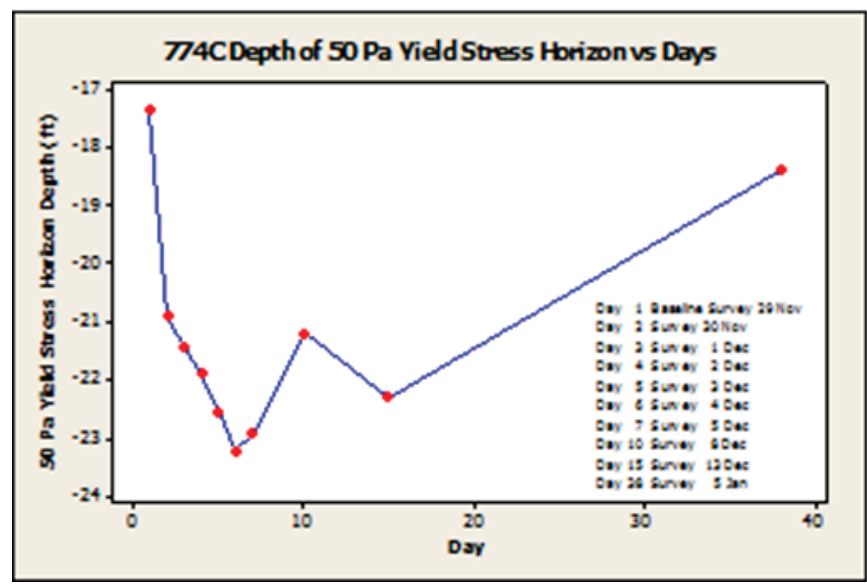

Station $774 \mathrm{C}$

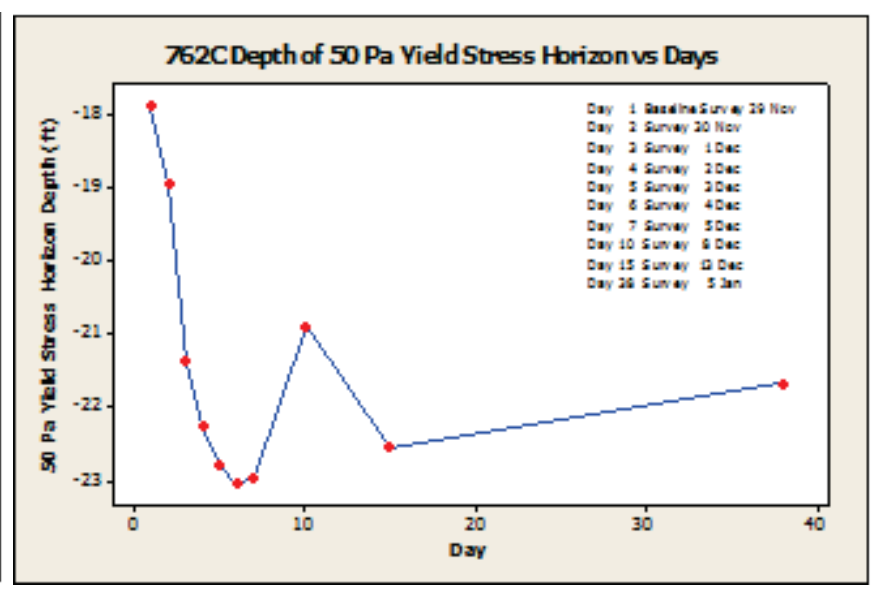

Station $762 \mathrm{C}$

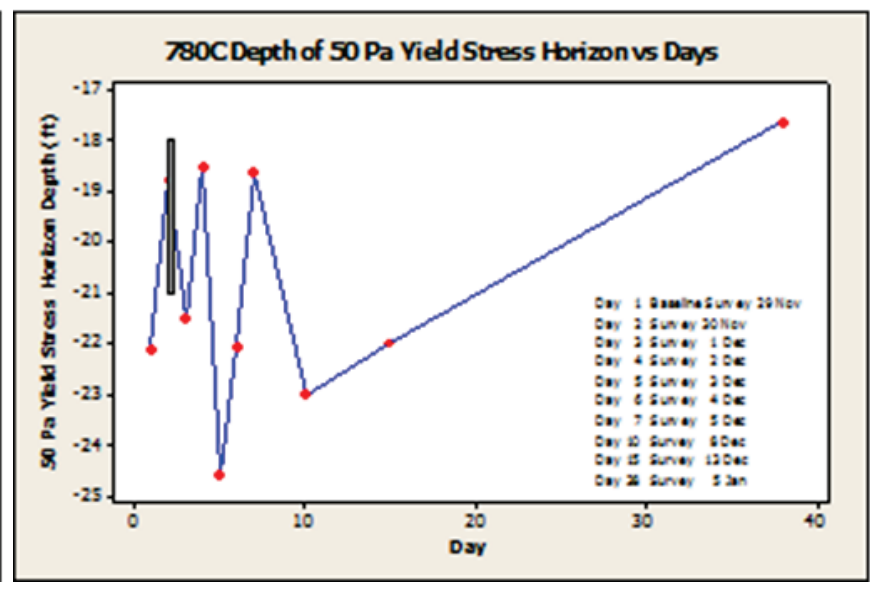

Station $780 \mathrm{C}$ 


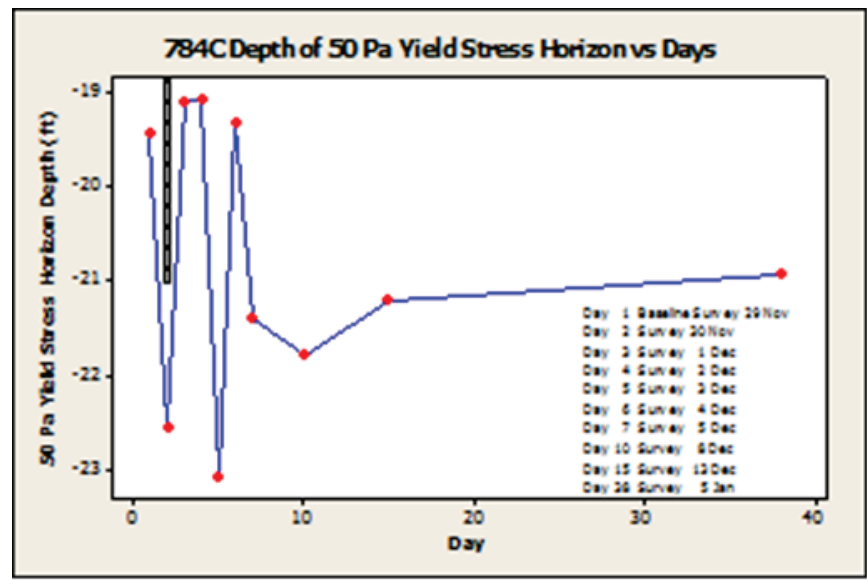

Station $784 \mathrm{C}$

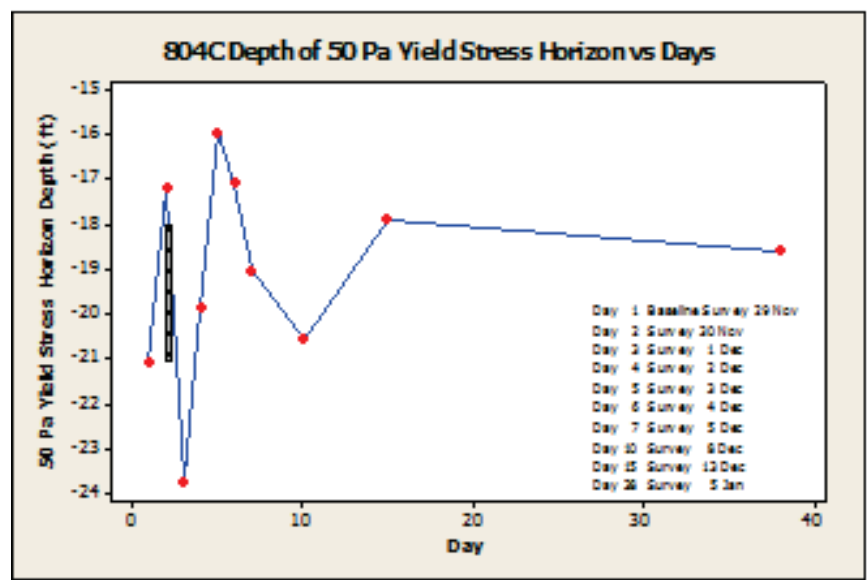

Station $804 C$

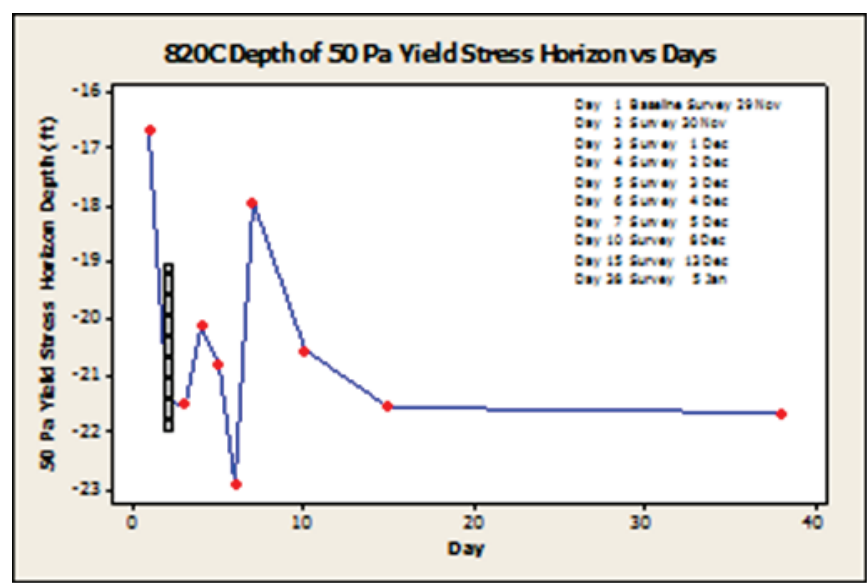

Station $820 C$

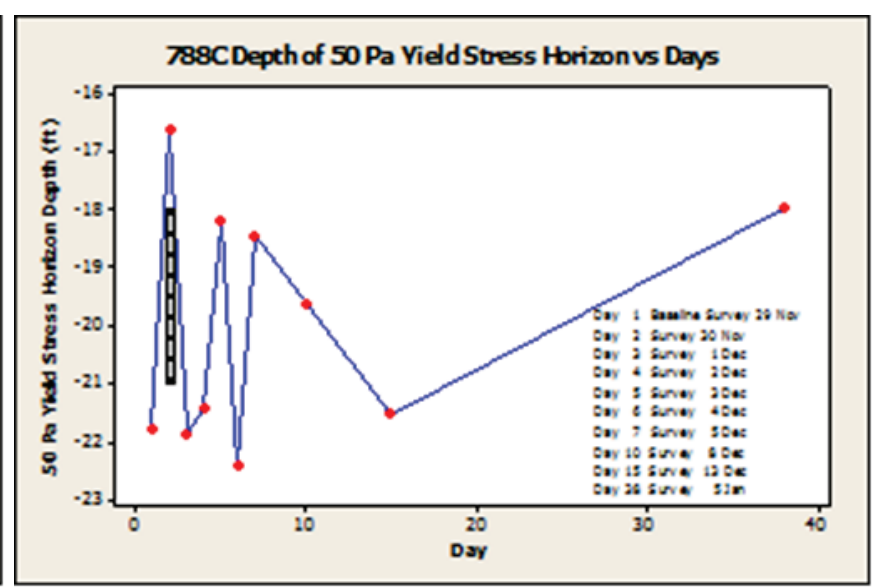

Station $788 \mathrm{C}$

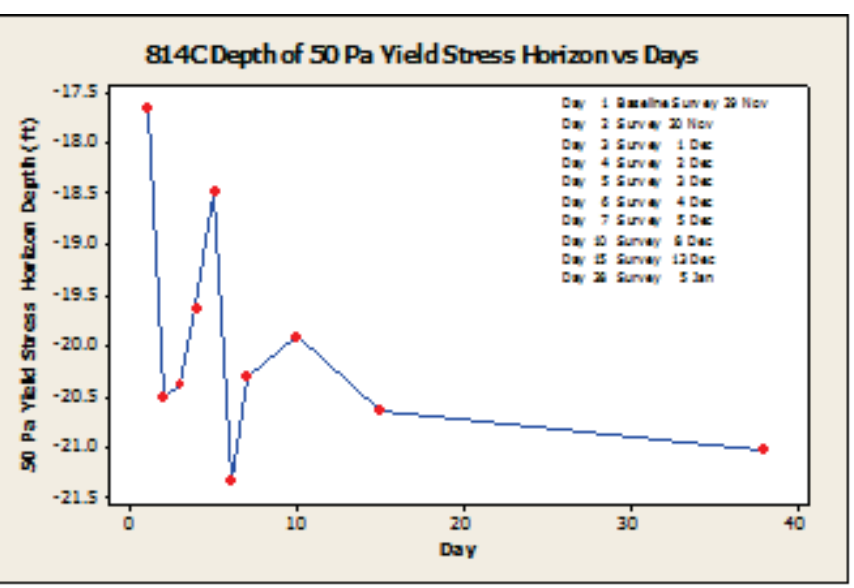

Station $814 \mathrm{C}$

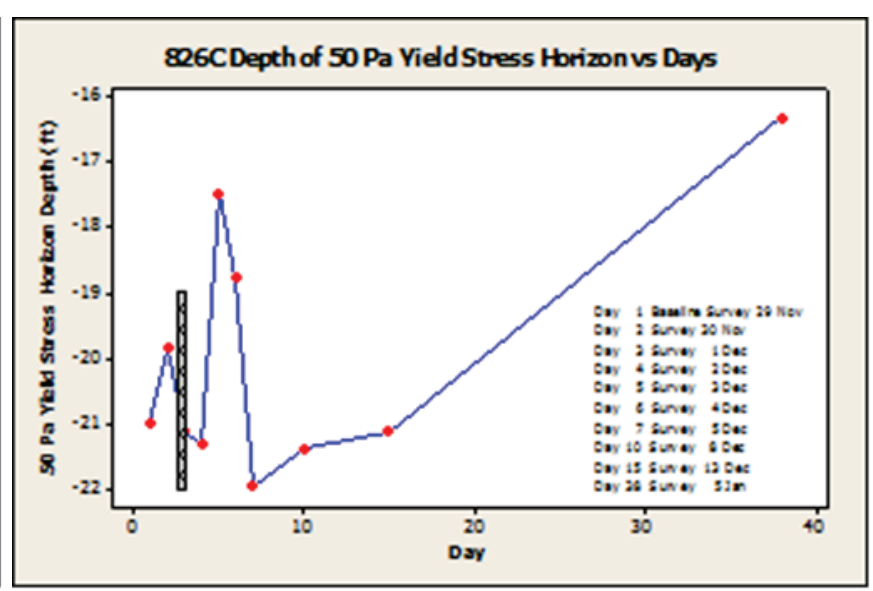

Station 826C 


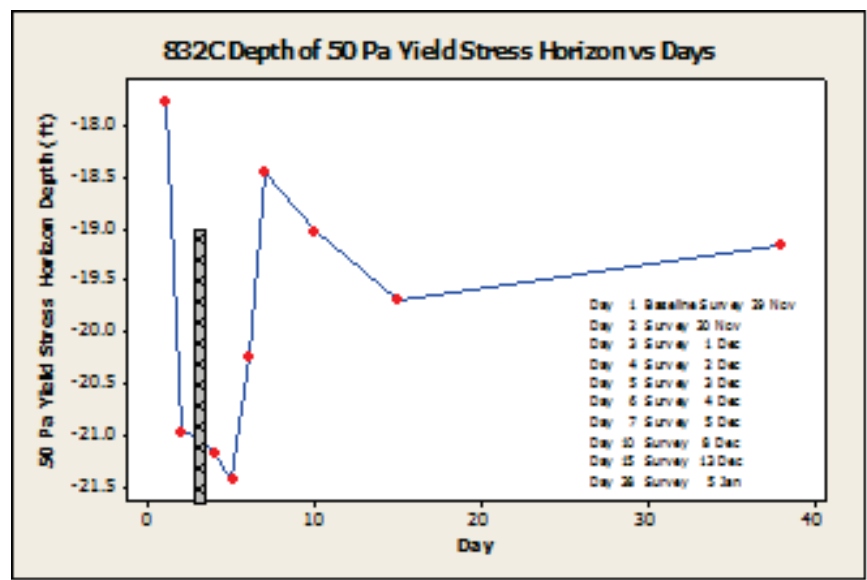

Station $832 \mathrm{C}$ 


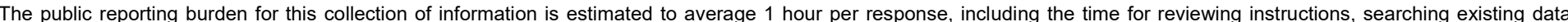

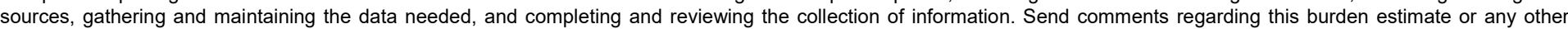

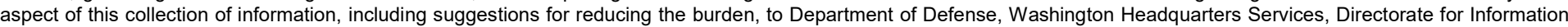

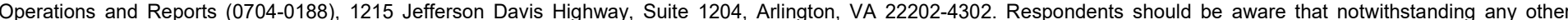
provision of law, no person shall be subject to any penalty for failing to comply with a collection of information if it does not display a currently valid OMB control number. PLEASE DO NOT RETURN YOUR FORM TO THE ABOVE ADDRESS.

\begin{tabular}{l|l|l}
\hline 1. REPORT DATE & $\begin{array}{l}\text { 2. REPORT TYPE } \\
\text { Technical Report }\end{array}$ & 3. DATES COVERED (FrOm - To) \\
August 2017 &
\end{tabular}

\section{TITLE AND SUBTITLE}

5a. CONTRACT NUMBER

Evaluation of the Use of a Bedleveler to Improve Navigability of Atchafalaya River

Bar Channel Fluid Mud

\section{5b. GRANT NUMBER}

\section{5c. PROGRAM ELEMENT NUMBER}

\section{AUTHOR(S)}

5d. PROJECT NUMBER

Michael Tubman, Timothy Welp, Mike Sullivan, and Chris Colombo

\section{5e. TASK NUMBER}

5f. WORK UNIT NUMBER

456009

\section{PERFORMING ORGANIZATION NAME(S) AND ADDRESS(ES)}

U.S. Army Corps of Engineers

Engineer Research and Development Center

8. PERFORMING ORGANIZATION

REPORT NUMBER

3909 Halls Ferry Road

Vicksburg MS, 39180

9. SPONSORING/MONITORING AGENCY NAME(S) AND ADDRESS(ES)

U.S. Army Corps of Engineers

ERDC/CHL TR-17-14

Washington, DC 20314-1000

10. SPONSOR/MONITOR'S ACRONYM(S) HQUSACE

11. SPONSOR/MONITOR'S REPORT NUMBER(S)

\section{DISTRIBUTION/AVAILABILITY STATEMENT}

Approved for public release; distribution is unlimited.

\section{SUPPLEMENTARY NOTES}

\section{ABSTRACT}

Between routine navigation dredging operations, the Atchafalaya River Bar Channel (ABC) traps fluid mud, which begins to consolidate. The consolidated mud can begin to block the passage of vessels using the Port of Morgan City, LA. If the mud densities and yield stresses could be kept sufficiently low so that vessels could safely navigate through it, the length of time between navigation dredging could potentially be increased. To demonstrate the feasibility of dragging a large object through the mud to condition the sediments, a bedleveler was constructed and suspended below a barge at depths that penetrated the interface between the water and the fluid mud in the channel (i.e., the lutocline). The barge was towed along the ABC parallel to its axis, thereby dragging the bedleveler through the fluid mud on the channel bottom.

It was found that dragging the bedleveler along the channel seemed to have no effect, or an extremely limited effect, over a short duration on the densities. It cannot be ruled out that the bedleveler operations had an effect on yield stresses, but the measured decreases were so inconsistent that naturally occurring changes or other factors had a larger effect.

\section{SUBJECT TERMS}

Atchafalaya River (La.), Barges, Bed leveler, Channels (Hydraulic engineering), Deep draft vessel, Dredging, Fluid mud, Hydrographic surveying, Mud-Density-Measurement, Nautical depth, Nautical bottom, Navigation, River sediment, Sediment conditioning

16. SECURITY CLASSIFICATION OF:

\begin{tabular}{|l|l|l|l|}
\hline a. REPORT & b. ABSTRACT & c. THIS PAGE & ABSTRACT \\
Unclassified & Unclassified & Unclassified & SAR \\
& & & \\
\hline
\end{tabular}

18. NUMBER OF PAGES 19a. NAME OF RESPONSIBLE PERSON Tim Welp 19b. TELEPHONE NUMBER (Include area code) 601-634-2083 